\title{
Cytoprotective effect of selective small-molecule caspase inhibitors against staurosporine-induced apoptosis
}

This article was published in the following Dove Press journal:

Drug Design, Development and Therapy

24 May 2014

Number of times this article has been viewed

\author{
Jianghong Wu \\ Yuren Wang \\ Shuguang Liang \\ Haiching $\mathrm{Ma}$
}

Reaction Biology Corp, Malvern, PA, USA
Correspondence: Haiching Ma Reaction Biology Corp, I Great Valley Parkway, Suite 2, Malvern, PA 19355, USA Tel + I 6107220247

Fax + I 6107220246

Email haiching.ma@reactionbiology.com
Abstract: Caspases are currently known as the central executioners of the apoptotic pathways. Inhibition of apoptosis and promotion of normal cell survival by caspase inhibitors would be a tremendous benefit for reducing the side effects of cancer therapy and for control of neurodegenerative disorders such as Parkinson's, Alzheimer's, and Huntington's diseases. The objective of this study was to discover small-molecule caspase inhibitors with which to achieve cytoprotective effect. We completed the high-throughput screening of Bionet's 37,500-compound library (Key Organics Limited, Camelford, Cornwall, UK) against caspase-1, -3, and -9 and successfully identified 43 initial hit compounds. The 43 hit compounds were further tested for cytoprotective activity against staurosporine-induced cell death in NIH3T3 cells. Nineteen compounds were found to have significant cytoprotective effects in cell viability assays. One of the compounds, RBC1023, was demonstrated to protect $\mathrm{NIH} 3 \mathrm{~T} 3$ cells from staurosporine-induced caspase-3 cleavage and activation. $\mathrm{RBC} 1023$ was also shown to protect against staurosporine-induced impairment of mitochondrial membrane potential. DNA microarray analysis demonstrated that staurosporine treatment induced broad global gene expression alterations, and RBC1023 co-treatment significantly restored these changes, especially of the genes that are related to cell growth and survival signaling such as Egrl, Cdc25c, cdkn3, Rhob, Nek2, and Taok1. Collectively, RBC1023 protects NIH3T3 cells against staurosporine-induced apoptosis via inhibiting caspase activity, restoring mitochondrial membrane potential, and possibly upregulating some cell survival-related gene expressions and pathways.

Keywords: cell death, caspase inhibition, mitochondria, RBC1023

\section{Introduction}

Apoptosis is a genetically programmed, morphologically distinct form of cell death that can be triggered by many chemicals in a variety of cellular events, such as calcium influx, oxidative stress, cytoskeletal interference, inhibitors of protein synthesis, membrane disruption, and DNA disruption induced by radiation. ${ }^{1}$ Caspases, currently known as the central executioners of the apoptotic pathways, are cysteine proteases that cleave substrates after aspartate residues, ${ }^{2-4}$ and at least 14 different subtypes have been identified in mammalian cells. Two pathways of caspase activation for apoptosis induction have been identified. The first one starts at death receptors such as Fas. ${ }^{5}$ In the second and more common pathway, diverse proapoptotic signals converge at the mitochondrial level, inducing the translocation of cytochrome $\mathrm{c}$ from mitochondria to cytoplasm, thereby triggering the cascade of caspase activation. ${ }^{6,7}$ Caspase- 3 is one of the most important and active executors in the apoptosis pathway.

Caspases are important targets of drug discovery ${ }^{8}$ because inhibition of apoptosis is a means of promoting cell survival. The significance of caspases in cancer therapy is 
implicated in two directions: while the activation of caspases leading to the cancer cell-specific apoptosis is critical to numerous and diverse cancer treatments, caspase inhibition in nonmalignant cells is a defined target for cytoprotection and reducing organ-specific toxicity during cancer therapy. ${ }^{9}$ The toxicity of normal cells exerted by chemotherapy and radiation therapy is often a limiting factor for optimal therapeutic dosage. Cytoprotection of nonmalignant cells by caspase inhibition would allow a higher upper limit of dose escalation of existing therapeutics to achieve maximal efficacy. Caspase inhibition has also been suggested for ultraviolet protection therapy to alleviate side effects such as ultraviolet-induced skin damage, inflammation, and aging. ${ }^{10-13}$ Furthermore, caspase inhibition may provide prevention or treatment against acute episodes such as stroke, traumatic brain injury, spinal cord injury, or myocardial infarction. Neuron-degenerative diseases, treatment of which may benefit from caspase inhibition, include amyotrophic lateral sclerosis, Parkinson's, Alzheimer's, and Huntington's. ${ }^{14}$

To discover new caspase inhibitors, we screened Bionet's 37,500-compound library against human caspase-1, -3, and -9 with the fluorogenic substrates Ac-YVAD-AMC, Ac-DEVDAMC, and Ac-LEHD-AMC, and identified 43 initial hit compounds. Using staurosporine-induced apoptosis assay in NIH3T3 cell line, we discovered 19 small molecules with cell protective activities, in which compound RBC1023, a selective caspase-3 inhibitor, had shown a broad protection spectrum across many different cell types. Further mechanistic studies indicated that RBC1023 protected NIH3T3 cells from staurosporine-induced caspase cleavage and activation and restored staurosporineinduced loss of mitochondrial membrane potential. Moreover, we investigated the changes in gene expression in NIH3T3 cells treated with staurosporine in the presence or absence of RBC1023 using a DNA microarray analysis to understand the molecular mechanisms of the cytoprotective effect of RBC1023.

\section{Materials and methods}

\section{Chemicals and reagents}

Bionet's 37,500-compound library was obtained from Key Organics Limited (Camelford, Cornwall, UK). Purified caspase-1, -3, and -9 enzymes; fluorogenic caspase substrates AcYVAD-AMC, Ac-DEVD-AMC, and Ac-LEHD-AMC; and control caspase inhibitor Ac-DEVD-CHO, Ac-LEHD-CHO, and Ac-YVAD-CHO were all obtained from Biomol International (Enzo Life Sciences, Inc., Farmingdale, NY, USA). Staurosporine was obtained from Sigma-Aldrich (St Louis, MO, USA). Cell Titer-Glo ${ }^{\circledR}$ Luminescent Cell Viability Assay Kit and Apo-ONE ${ }^{\circledR}$ Homogeneous Caspase-3/7 Assay Kit were obtained from Promega Corporation (Fitchburg, WI, USA).
MTT (3-(4,5-dimethylthiazol-2-yl)-2,5-diphenyltetrazolium bromide) Cell Proliferation Assay Kit was obtained from Cayman Chemical (Ann Arbor, MI, USA). JC-10 Mitochondrial Membrane Potential Assay Kit was obtained from Abcam (Cambridge, UK). Anti-caspase-3 polyclonal antibody (catalog\#9665, 1:2000 dilutions) was obtained from Cell Signaling Technology (Danvers, MA, USA). Anti- $\alpha$-tubulin monoclonal antibody (catalog\#T6074, 1:5000 dilutions) was obtained from Sigma-Aldrich. The secondary antibodies Alexa Fluor ${ }^{\circledR} 633$ goat anti-rabbit immunoglobulin (Ig)G (heavy and light chains $[\mathrm{H}+\mathrm{L}]$ ) and Alexa Fluor ${ }^{\circledR} 532$ goat anti-mouse $\operatorname{IgG}(\mathrm{H}+\mathrm{L})$ were obtained from Thermo Fisher Scientific (Life Technologies, Waltham, MA, USA). Other chemicals were of reagent grade and were obtained from Sigma-Aldrich or VWR International (Radnor, PA, USA).

\section{High-throughput screening (HTS) and hit confirmation}

The primary HTS against caspase-1, -3 , and -9 enzymes was performed using the Bionet compound library. In brief, $5 \mu \mathrm{L}$ of reaction buffer (50 $\mathrm{mM}$ 4-(2-hydroxyethyl)piperazine-1ethanesulfonic acid (HEPES) pH 7.4, $100 \mathrm{mM} \mathrm{NaCl}, 0.1 \%$ 3-[(3-cholamidopropyl) dimethylammonio]-1-propanesulfonate (CHAPS), $1 \mathrm{mM}$ ethylenediaminetetraacetic acid (EDTA), and $3 \mathrm{mM}$ dithiothreitol) with $1 \mathrm{X}$ enzyme was added to each well of Genetix 7020 low-volume 384-well plates (Molecular Devices LLC, Sunnyvale, CA, USA). Five nanoliters of $10 \mathrm{mM}$ of each compound from the Bionet 37,500-compound library was delivered to each well of the Genetix plates (final compound concentration $10 \mu \mathrm{M}$ ) by acoustic droplet ejection liquid handler (Echo 550, Labcyte Inc., Sunnyvale, CA, USA). The plates were shaken to mix for 1 minute. One microliter of positive control inhibitors (Ac-YVAD-CHO, Ac-DEVD-CHO, and Ac-LEHD$\mathrm{CHO}$ ) was added to the control wells. Ten nanoliters of $5 \mathrm{mM}$ of caspase substrates was delivered to the plates by Echo 550 to start the reaction. The fluorescent signal was measured by EnVision $^{\circledR} 2104$ Multilabel Reader (PerkinElmer Inc., Waltham, MA, USA) at an excitation wavelength of $355 \mathrm{~nm}$ and an emission wavelength of $460 \mathrm{~nm}$ at the 2 -hour time point. The fluorescent signal generated was proportional to the caspase- $1,-3$, and -9 activities. The initial hits from the HTS were cherry-picked and further tested in a ten-dose half maximal inhibitory concentration (IC-50)-mode against caspase-1, -3, and -9.

\section{Cells, cell culture, and compound treatment}

NIH3T3 mouse fibroblast, PC12 rat pheochromocytoma cells, and U87MG human glioblastoma cells were 
obtained from American Type Culture Collection (ATCC) (Manassas, VA, USA). SH-SY5Y cell line was kindly provided by Dr Honglin Zhou at the University of Pennsylvania (Philadelphia, PA, USA). NIH3T3 cells were grown in Dulbecco's Modified Eagle's Medium, PC12 cells were grown in RPMI 1640 (Roswell Park Memorial Institute medium 1640), U87MG cells were grown in Modified Eagle's Medium, and SH-SY5Y cells were grown in a 1:1 mixture of Modified Eagle's Medium and F12 media. All culture media were supplemented with $10 \%$ heat-inactivated fetal bovine serum, $100 \mu \mathrm{g}$ $\mathrm{mL}$ penicillin, and $100 \mu \mathrm{g} / \mathrm{mL}$ streptomycin. Cultures were maintained at $37^{\circ} \mathrm{C}$ in a humidified atmosphere of $5 \% \mathrm{CO}_{2}$ and $95 \%$ air. For most experiments, unless specified, 5,000/ well of logarithmically growing cells were seeded in each of the 384 -well plates containing proper medium plus $1 \%$ fetal bovine serum with or without compound. Dimethyl sulfoxide ([DMSO] $\leq 0.3 \%$ ) was added to all the control cultures.

\section{Cell Titer-Glo ${ }^{\circledR}$ Luminescent Cell Viability Assay and adenosine triphosphate (ATP) measurement}

NIH3T3, PC12, U87MG, or SH-SY5Y cells were seeded overnight in triplicates in 384-well plates. The cells were incubated with compounds for 24 hours. A volume of Cell Titer-Glo ${ }^{\circledR}$ reagent equal to the volume of cell culture medium was added to each well. Contents were mixed for 2 minutes on an orbital shaker to induce cell lysis. The plates were incubated at room temperature for 10 minutes to stabilize luminescent signal. Luminescence was recorded by the EnVision $^{\circledR} 2104$ Multilabel Reader. The numbers of viable cells in culture were determined based on quantitation of the ATP present in each well. For quantifying cellular ATP contents in NIH3T3 cells, an ATP standard curve was generated starting at $1 \mu \mathrm{M}$ in serial ten-fold dilutions in culture medium. The luminescence signals were converted into ATP concentration based on the ATP standard curve.

\section{Apo-ONE ${ }^{\circledR}$ Homogeneous Caspase-3/7 Assay}

NIH3T3 cells were seeded overnight in triplicates in 384-well plates. The cells were incubated with compounds for 6 hours. A volume of Apo-ONE ${ }^{\circledR}$ reagent equal to the volume of cell culture medium was added to each well. The contents were gently mixed using a plate shaker at $300 \mathrm{rpm}$ for 30 seconds. The plates were incubated at room temperature for 30 minutes. Upon the cleavage of caspase substrate Z-DEVD-rhodamine 110, bis-(N-CBZ-L-aspartyl-L-glutamyl-L-valyl-L-aspartic acid amide) by caspase-3/7 activity, the fluorescence of each well was measured at an excitation wavelength of $485 \mathrm{~nm}$ and an emission wavelength of $535 \mathrm{~nm}$ using the EnVision ${ }^{\circledR}$ 2104 Multilabel Reader. The amount of fluorescence generated was proportional to the amount of caspase- $3 / 7$ cleavage activity present in the sample.

\section{MTT cell proliferation assay}

NIH3T3 cells were seeded in triplicates in 96-well plates at a density of $2 \times 10^{4}$ cells/well in $100 \mu \mathrm{L}$ of culture medium with or without compounds to be tested. The cells were cultured in a $\mathrm{CO}_{2}$ incubator at $37^{\circ} \mathrm{C}$ for 24 hours. Ten microliters of MTT reagent was added to each well and mixed gently for 1 minute. The cells were incubated for 4 hours at $37^{\circ} \mathrm{C}$. After incubation, the formazan produced in the cells appeared as dark crystals in the bottom of the wells. The culture medium from each well was aspirated carefully and $100 \mu \mathrm{L}$ of crystal-dissolving solution was added to each well to dissolve the formazan crystals. The absorbance of each sample was quantified at $590 \mathrm{~nm}$ using the EnVision ${ }^{\circledR} 2104$ microplate reader. The absorbance intensity was proportional to the amount of viable cells.

\section{JC-I0 mitochondrial membrane potential assay}

Mitochondrial membrane potential $(\Delta \psi \mathrm{m})$ was evaluated by cationic dye JC-10. In normal cells, JC-10 aggregates in mitochondria, fluorescing red. In apoptotic cells, JC-10 accrues in the cytosol, as a green fluorescing monomer. Briefly, NIH3T3 cells were plated in triplicates in growth medium in 384-well plates overnight. The cells were treated with or without compounds for 6 hours. JC-10 dye-loading solution was added and the plates were incubated in a $37^{\circ} \mathrm{C}, 5 \% \mathrm{CO}_{2}$ incubator for 30 minutes. Assay buffer was added into the dye-loading plates and the fluorescence intensities were monitored at excitation/ emission $=485 / 535 \mathrm{~nm}$ and $485 / 590 \mathrm{~nm}$ for ratio analysis in the EnVision ${ }^{\circledR} 2104$ Multilabel microplate reader.

\section{Western blot analysis}

NIH3T3 cells were seeded in six-well plates $\left(0.8 \times 10^{6}\right.$ cells $/$ well $)$ and treated with or without compounds for 6 hours. After the treatment, cells were washed with cold phosphate-buffered saline and lysed in cell lysis buffer $(150 \mathrm{mM}$ $\mathrm{NaCl}, 1 \%$ Triton X-100, $50 \mathrm{mM}$ Tris $\mathrm{pH} 7.5$, proteinase inhibitor cocktail, $0.1 \mathrm{mM}$ phenylmethylsulfonyl fluoride). Protein concentrations of the cell lysates were measured using Bio-Rad protein assay dye reagent concentrate (Bio-Rad Laboratories Inc., Hercules, CA, USA). About $30 \mu \mathrm{g}$ of total protein for each sample was separated under reducing conditions by sodium dodecyl sulfate polyacrylamide gel electrophoresis 
(SDS-PAGE) and transferred to a nitrocellulose membrane (Life Technologies). The blots were blocked in 3\% nonfat milk for 2 hours at room temperature with gentle shaking. This was followed by incubation with the respective antibody overnight at $4^{\circ} \mathrm{C}$ and then incubation with Alexa Fluor ${ }^{\circledR} 633$ goat antirabbit IgG or Alexa Fluor ${ }^{\circledR} 532$ goat anti-mouse IgG secondary antibody for 1 hour. Fluorescence signals of the immune complexes were scanned with a Typhoon 8610 variable mode imager (GE Healthcare Bio-Sciences Corp, Piscataway, NJ, USA).

\section{DNA microarray analysis of gene expression profile}

NIH3T3 cells were seeded in $10 \mathrm{~cm}$ dishes $\left(2 \times 10^{6}\right.$ cells $/$ dish $)$ and treated with DMSO or testing compounds. The cells were pelleted down by centrifuging and washed by cold phosphate-buffered saline. The cell pellets were frozen using dry ice, and submitted to the Penn Molecular Profiling Facility (University of Pennsylvania School of Medicine) for RNA extraction and transcript profiling. Microarray analysis was conducted in duplicate. RNA was extracted with TRIzol $^{\circledR}$ by Life Technologies (Thermo Fisher Scientific) and purified using the Qiagen RNeasy Kit (Qiagen NV, Venlo, the Netherlands); total RNA yields ranged from 15.5 to $53.4 \mu \mathrm{g}$ per sample with A260/280 of 2.07-2.18. Transcript profiling was conducted as described in the Affymetrix GeneChip Expression Analysis Technical Manual (Affymetrix Inc., Santa Clara, CA, USA). ${ }^{15}$ Briefly, $100 \mathrm{ng}$ of total RNA was converted to first-strand complementary DNA (cDNA) using reverse transcriptase primed by poly (T) and random oligomers that incorporated the $\mathrm{T} 7$ promoter sequence. Second-strand cDNA synthesis was followed by in vitro transcription with T7 RNA polymerase for linear amplification of each transcript, and the resulting cRNA was converted to cDNA, fragmented, and biotinylated by terminal transferase end labeling. Labeled cDNA was added to Affymetrix hybridization cocktails, heated at $99^{\circ} \mathrm{C}$ for 5 minutes, and hybridized for 16 hours at $45^{\circ} \mathrm{C}$ to GeneChip Mouse Gene 1.0ST Arrays (Affymetrix Inc.). The microarrays were then washed at low $(6 \times$ SSPE [sodium chloride, sodium phosphate monobasic, and ethylenediaminetetraacetic acid]) and high (100 mM MES [2-[N-morpholino] ethanesulfonic acid, tris base, ethylenediaminetetraacetic acid, and sodium dodecyl sulfate], $0.1 \mathrm{M} \mathrm{NaCl}$ ) stringency, and stained with streptavidin/phycoerythrin. Fluorescence was amplified by adding biotinylated anti-streptavidin and an additional aliquot of streptavidin/phycoerythrin stain. A confocal scanner was used to collect the fluorescence signal after excitation at $570 \mathrm{~nm}$. The intensity of the fluorescence signal was proportional to the levels of gene expression.

\section{Statistical analysis}

Statistical analysis in this study was performed using the unpaired Student's $t$-test or one-way analysis of variance (ANOVA). The values are represented as mean \pm standard deviation. A $P$-value $<0.05$ was considered to be statistically significant.

\section{Results}

\section{HTS and hit confirmation}

Using the Bionet 37,500-compound library, we successfully completed HTS against human caspase-1, -3, and -9 . The screening was of high quality, with a robust $Z$-factor $>0.6$ (Table 1). ${ }^{16}$ By using simple signal-to-noise analysis, compounds with response signal $>3$ times the standard deviation of the noise were designated as "hits". Totals of 453 compounds, 727 compounds, and 1,149 compounds were selected as initial hits for caspase-1, -3 , and -9 , respectively, which represent the hit rates of $1.20 \%$, $1.94 \%$, and $3.06 \%$, respectively (Table 1 ). The hits were further confirmed in ten-dose IC50 mode in the presence of three different reducing agents ( $3 \mathrm{mM}$ dithiothreitol, 5 $\mathrm{mM} \beta$-mercaptoethanol, $5 \mathrm{mM}$ cysteine) to eliminate any reactive electrophilic compounds. ${ }^{17}$ There were 143, 178, and 273 confirmed hits that inhibited caspase-1, -3 , or -9 , respectively. This provided overall hit rates of $0.38 \%, 0.47 \%$, and $0.73 \%$, respectively, which are typical for biochemical HTS against a diversity library. We further eliminated some compounds from these confirmed hits using three stringent selection processes: compounds with $>20 \%$ inhibition on cytochrome P450 (Cyp) enzymes such as Cyp2C19, Cyp1A2, Cyp2A6, Cyp2C9, Cyp3A4, or Cyp2D6 at $10 \mu \mathrm{M}$ (data not shown); compounds containing undesirable structures and metabolically fragile functionality (such as reactive chlorides, Michael acceptors, thiols, esters, quaternary salts, and detergents); and compounds showing significant toxicity against mouse embryonic fibroblast cells (data not shown). A final set of 43 compounds was selected for further testing in a cytoprotection assay (Table 2 ).

Table I Primary high-throughput screening (HTS) of caspase- I, -3 , and -9

\begin{tabular}{|c|c|c|c|}
\hline Target & Caspase-I & Caspase-3 & Caspase-9 \\
\hline Compounds screened & 37,500 & 37,500 & 37,500 \\
\hline HTS hits & 453 & 727 & 1,149 \\
\hline Z-factor & $>0.6$ & $>0.6$ & $>0.6$ \\
\hline Primary hit rate & $1.21 \%$ & $1.94 \%$ & $3.06 \%$ \\
\hline Confirmation under & 143 & 178 & 273 \\
\hline \multicolumn{4}{|c|}{ three different reducing agents } \\
\hline Confirmation rate & $0.38 \%$ & $0.47 \%$ & $0.73 \%$ \\
\hline
\end{tabular}


Table 2 Caspase inhibition activity IC50 ( $\mu \mathrm{M})$ of 43 hit compounds from the in vitro caspase- $1,-3$, and -9 screening assays

\begin{tabular}{|c|c|c|c|}
\hline Compound \# & Caspase-I & Caspase-3 & Caspase-9 \\
\hline $\mathrm{RBCI00I}$ & 1.84 & 8.36 & 1.84 \\
\hline $\mathrm{RBCl} 002$ & 0.36 & $>20$ & 0.36 \\
\hline $\mathrm{RBCl} 003$ & $>20$ & $>20$ & 0.14 \\
\hline $\mathrm{RBCl} 004$ & 14.25 & $>20$ & 0.65 \\
\hline $\mathrm{RBCl} 005$ & $>20$ & $>20$ & 0.55 \\
\hline $\mathrm{RBCI006}$ & $>20$ & $>20$ & 1.08 \\
\hline $\mathrm{RBCl007}$ & $>20$ & $>20$ & 0.35 \\
\hline $\mathrm{RBCl} 008$ & $>20$ & $>20$ & 0.15 \\
\hline $\mathrm{RBCl} 009$ & $>20$ & $>20$ & 0.06 \\
\hline RBCIOIO & $>20$ & $>20$ & 0.72 \\
\hline RBCIOII & $>20$ & $>20$ & 3.25 \\
\hline $\mathrm{RBClOI2}$ & $>20$ & $>20$ & 0.40 \\
\hline $\mathrm{RBCIOI3}$ & $>20$ & $>20$ & 0.50 \\
\hline $\mathrm{RBClOI4}$ & $>20$ & $>20$ & 1.20 \\
\hline $\mathrm{RBClOI5}$ & $>20$ & 1.13 & $>20$ \\
\hline $\mathrm{RBCl} 016$ & $>20$ & $>20$ & 1.38 \\
\hline $\mathrm{RBCIOI7}$ & $>20$ & $>20$ & 3.31 \\
\hline $\mathrm{RBCI0I8}$ & 12.90 & $>20$ & 0.60 \\
\hline $\mathrm{RBClOI9}$ & 12.08 & $>20$ & 4.77 \\
\hline $\mathrm{RBClO} 020$ & $>20$ & $>20$ & 1.38 \\
\hline $\mathrm{RBCl02I}$ & $>20$ & 1.41 & $>20$ \\
\hline $\mathrm{RBCl} 022$ & $>20$ & $>20$ & 2.66 \\
\hline $\mathrm{RBCl} 023$ & $>20$ & 0.38 & $>20$ \\
\hline $\mathrm{RBCl} 024$ & $>20$ & 4.84 & 3.05 \\
\hline $\mathrm{RBCl} 025$ & 12.00 & $>20$ & 0.56 \\
\hline $\mathrm{RBCl} 026$ & $>20$ & $>20$ & 0.61 \\
\hline $\mathrm{RBCl} 027$ & $>20$ & $>20$ & 0.06 \\
\hline $\mathrm{RBCl} 028$ & $>20$ & $>20$ & 2.82 \\
\hline $\mathrm{RBCl} 029$ & $>20$ & $>20$ & 0.15 \\
\hline $\mathrm{RBCl} 030$ & 17.06 & $>20$ & 1.80 \\
\hline $\mathrm{RBCl03I}$ & $>20$ & $>20$ & 3.94 \\
\hline $\mathrm{RBCl} 032$ & $>20$ & 8.08 & 0.03 \\
\hline $\mathrm{RBCl} 033$ & 14.72 & $>20$ & 2.34 \\
\hline $\mathrm{RBCl034}$ & $>20$ & 8.94 & 3.42 \\
\hline $\mathrm{RBCl} 035$ & $>20$ & 3.05 & $>20$ \\
\hline $\mathrm{RBCl} 036$ & 14.58 & $>20$ & 0.15 \\
\hline $\mathrm{RBCl} 037$ & $>20$ & 1.37 & $>20$ \\
\hline $\mathrm{RBCl} 038$ & 14.02 & $>20$ & 0.39 \\
\hline $\mathrm{RBCl} 039$ & $>20$ & $>20$ & 0.51 \\
\hline $\mathrm{RBCl} 040$ & $>20$ & $>20$ & 1.76 \\
\hline $\mathrm{RBCl04I}$ & 2.47 & $>20$ & 5.93 \\
\hline $\mathrm{RBCl} 042$ & $>20$ & 7.74 & 2.51 \\
\hline RBCI043 & $>20$ & 0.40 & $>20$ \\
\hline
\end{tabular}

Abbreviation: IC50, half maximal inhibitory concentration.

\section{Cytoprotective activities of the caspase inhibitors}

Staurosporine is a broad-spectrum inhibitor of protein kinases, and has been widely used in the induction of apoptosis in diverse cellular models. ${ }^{18-22}$ Staurosporine preferentially activates the mitochondrial apoptotic pathway relying on caspase activation and causes cell death. To confirm the caspase inhibition of the hit compounds in cell-based assay, NIH3T3 cells were treated with $20 \mu \mathrm{M}$ of each of the 43 hit compounds in the presence or absence of $1 \mu \mathrm{M}$ staurosporine for 24 hours. Then, cell viability was assessed by Cell Titer-Glo ${ }^{\circledR}$ Luminescent Cell Viability Assay. As shown in Figure 1, while staurosporine treatment alone caused over $90 \%$ cell death, 19 compounds showed significant protection against staurosporine-induced cell death in NIH3T3 cells $(P<0.01)$. Several compounds that are toxic to cells alone were removed from the hit list (data not shown). Compound RBC1020 (a caspase-9 selective inhibitor) and RBC1023 (a caspase-3 selective inhibitor) with no cytotoxicity alone demonstrated 7.5-fold and 5.9-fold increases respectively of cell viability compared to cells treated with staurosporine alone, indicating a strong cytoprotective activity of these two compounds. Caspase inhibitors could have potential application in treating neurodegenerative diseases such as Parkinson's and Alzheimer's diseases, which are usually associated with neuron cell death. Therefore, we extended the study to further examine the cytoprotective activity of the leads RBC1020 and RBC1023 in several neural origin cell types. PC12, U87MG, and SH-SY5Y cells were treated with DMSO, staurosporine alone, $\mathrm{RBC} 1020$ or $\mathrm{RBC} 1023$ alone, or $\mathrm{RBC} 1020$ or $\mathrm{RBC} 1023$ plus staurosporine for 24 hours and then the cell viability was examined. As shown in Figure 2, quantitative measurement of cell viability showed that $\mathrm{RBC} 1023$ increased the percentage of staurosporine-treated viable cells from $4 \%$ to $66 \%$ in PC12 cells, from $8 \%$ to $71 \%$ in U87MG cells, and from $6 \%$ to $47 \%$ in SH-SY5Y cells. Interestingly, RBC1020 had no or minimum cytoprotection in these three cell lines. It is still unknown why RBC1020 and RBC1023 showed different effects in different cell lines. Additional studies are needed to investigate the mechanism that causes this difference. These results demonstrated that $\mathrm{RBC1023}$, a selective caspase-3 inhibitor, exhibits strong cytoprotective effect against staurosporine-induced cell death in multiple cell lines.

\section{Dose-dependent and time- dependent study of RBCIO23 against staurosporine-induced cell death}

Since the staurosporine/NIH3T3 apoptosis induction system is a very well-established model system for apoptosis-related mechanism studies, we next focused on the cytoprotection mechanism studies in the NIH3T3 cell line. We first investigated the protective effect of different concentrations of RBC1023 against different concentrations of staurosporine-induced cell death. NIH3T3 cells were treated with different dose combinations of RBC1023 (50 $\mu \mathrm{M}$ to $1 \mu \mathrm{M}$, three-fold dilution, ten doses) and staurosporine $(0.768 \mu \mathrm{M}$ or $2 \mu \mathrm{M})$ for 24 hours before the cell viability was measured. As shown in Figure 3A, $\mathrm{RBC} 1023$ started to show significant cytoprotection against the staurosporine-induced cell death at about $2 \mu \mathrm{M}$, when the concentration of staurosporine was at $0.768 \mu \mathrm{M}$. The cytoprotective 
A

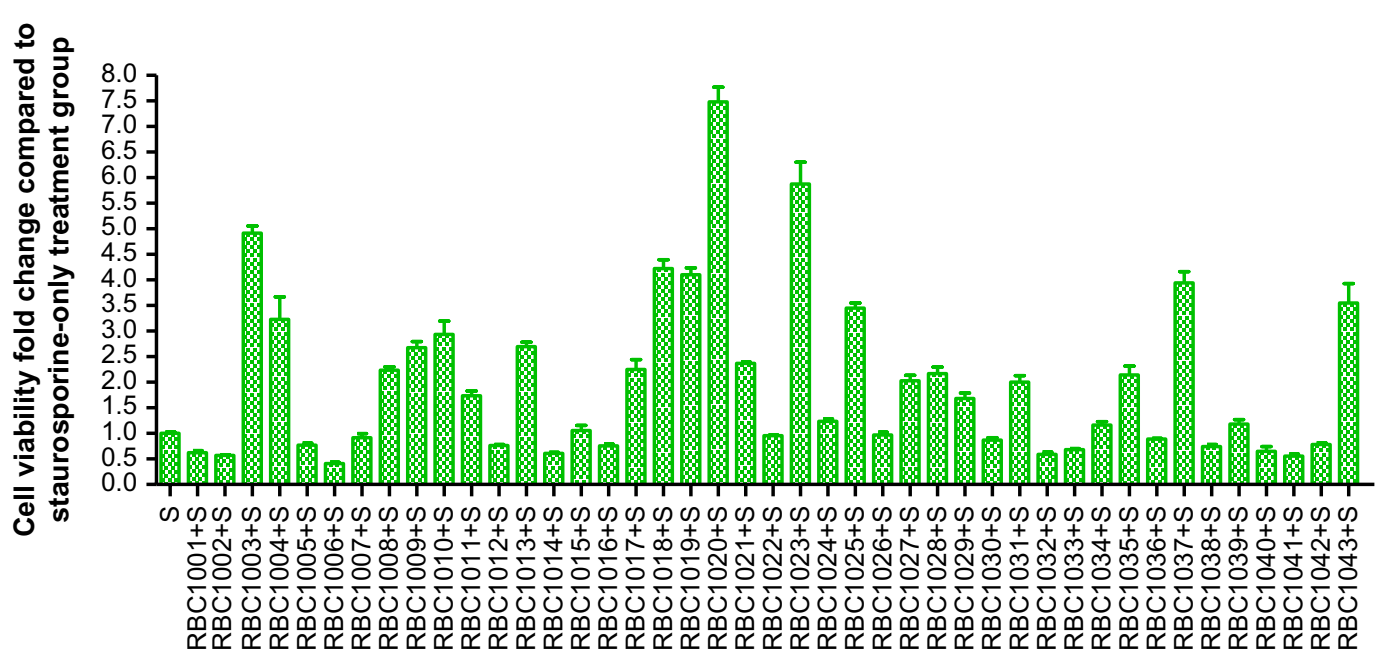

B

\begin{tabular}{ccc}
\hline Comparison groups & Fold change & $P$ value \\
\hline RBC1020+S vs S & 7.5 & 0.0001 \\
RBC1023+S vs S & 5.9 & 0.0003 \\
RBC1003+S vs S & 4.9 & 0.0001 \\
RBC1018+S vs S & 4.2 & 0.0001 \\
RBC1019+S vs S & 4.1 & 0.0001 \\
RBC1037+S vs S & 3.9 & 0.0002 \\
RBC1043+S vs S & 3.5 & 0.0026 \\
RBC1025+S vs S & 3.4 & 0.0001 \\
RBC1004+S vs S & 3.2 & 0.0073 \\
RBC1010+S vs S & 2.9 & 0.0017 \\
RBC1009+S vs S & 2.7 & 0.0002 \\
RBC1013+S vs S & 2.7 & 0.0001 \\
RBC1021+S vs S & 2.4 & 0.0001 \\
RBC1008+S vs S & 2.2 & 0.0001 \\
RBC1017+S vs S & 2.2 & 0.0031 \\
RBC1028+S vs S & 2.2 & 0.0009 \\
RBC1035+S vs S & 2.1 & 0.0029 \\
RBC1027+S vs S & 2 & 0.0008 \\
RBC1031+S vs S & 2 & 0.0016 \\
\hline
\end{tabular}

Figure I Screening results for cytoprotection of 43 hit compounds against staurosporine (S)-induced cell death in NIH3T3 cells.

Notes: (A) NIH3T3 cells were treated with dimethyl sulfoxide, $20 \mu \mathrm{M}$ of each of the 43 hit compounds, I $\mu \mathrm{M}$ of $\mathrm{S}$, or $20 \mu \mathrm{M}$ of each hit compound plus I $\mu \mathrm{M}$ of $\mathrm{S}$ for 24 hours. The cells were measured for viability by Cell Titer-Glo ${ }^{\circledR}$ luminescent assay (Promega Corporation, Fitchburg, WI, USA). The cell viability fold change between the combination group and $\mathrm{S}$ treatment group is presented. (B) Nineteen compounds were shown to have significant protection against $\mathrm{S}$-induced cell death. The $P$-values between the two indicated groups were calculated by Student's $t$-test. $P<0.01$ demonstrates a highly significant difference between the indicated groups.

Abbreviation: vs, versus.

effect by RBC1023 increased in a dose-dependent manner. To understand if the pretreatment or posttreatment of the caspase inhibitor would affect its cytoprotective effect, RBC1023 was added to cells at 1 hour before staurosporine treatment or 1 hour post-staurosporine treatment. The cell viability was measured after a total of 24 hours' incubation. Interestingly, there were no significant differences of cytoprotective activity by $\mathrm{RBC} 1023$ between the 1-hour pretreatment and and 1-hour posttreatment group with staurosporine (Figure 3B).

\section{RBCI 023 blocks staurosporine-induced caspase activation in cell-based assays}

To confirm RBC1023 as a caspase inhibitor in cell-based assays, we examined the caspase activity/activation-inducing effect in NIH3T3 cells that were treated with staurosporine in the presence or absence of $\mathrm{RBC} 1023$. As shown in Figure 4A, 6-hour staurosporine treatment induced significant caspase activation in NIH3T3 cells, as evaluated by Apo-ONE ${ }^{\circledR}$ Homogeneous Caspase-3/7 Assay using Z-DEVD-rhodamine 110 as a caspase substrate. Treatment of NIH3T3 cells with staurosporine for 6 hours also resulted in cleavage/activation of caspase-3, as was evident by the appearance of a $17 \mathrm{kD}$ proteolytic product of caspase- 3 as determined by Western blot analysis (Figure 4B). RBC1023 dramatically inhibited staurosporine-induced caspase-3 cleavage and activation (Figure 4B). These results confirmed that $\mathrm{RBC} 1023$ is a caspase inhibitor in cells. 
A

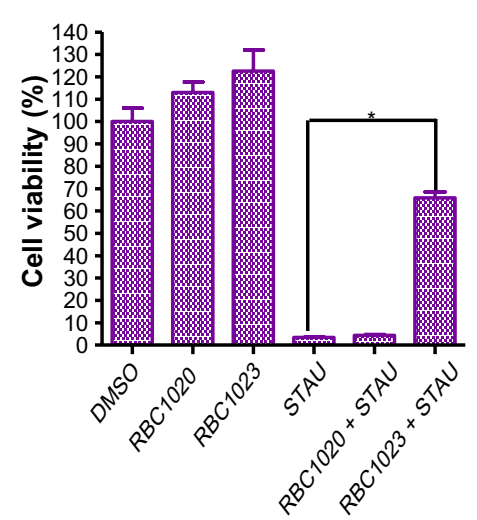

B

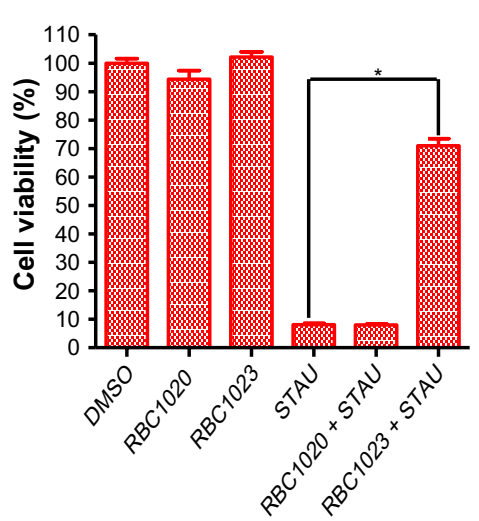

SH-SY5Y cells

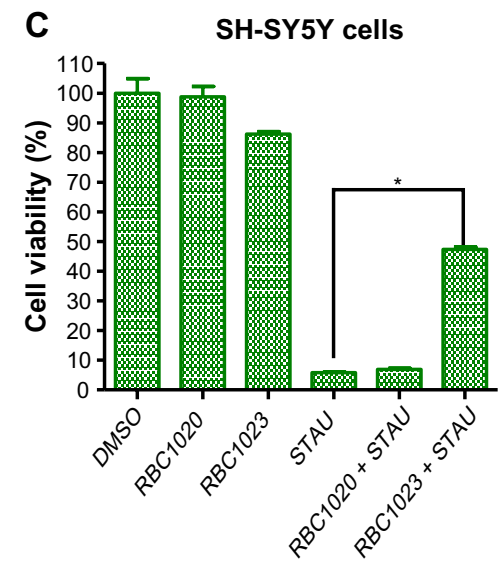

Figure 2 RBCI 023 protects STAU-induced cell death in PC-I2, U87MG, and SH-SY5Y cells.

Notes: PC-12 (A), U87MG (B), and SH-SY5Y (C) cells were treated with DMSO, $20 \mu \mathrm{M}$ of RBCI023, I $\mu$ M of STAU, or $20 \mu \mathrm{M}$ of RBCI023 plus I $\mu$ M of STAU, $20 \mu \mathrm{M}$ of RBCI 020 and $20 \mu \mathrm{M}$ of RBCI020 plus I $\mu \mathrm{M}$ of STAU for 24 hours. The cells were measured for viability by Cell Titer-Glo ${ }^{\circledR}$ luminescent assay (Promega Corporation, Fitchburg, WI, USA). $* P<0.0$ I (a highly significant difference between the indicated groups) by Student's $t$-test.

Abbreviations: DMSO, dimethyl sulfoxide; STAU, staurosporine.

\section{RBCl 023 restores NIH3T3 cells from the staurosporine-induced loss of cell viability and cellular ATP contents}

To investigate if $\mathrm{RBC} 1023$ can rescue staurosporineinduced decrease of cell viability, we performed the MTT assay, in which the tetrazolium dye, MTT, is reduced to formazan by intracellular nicotinamide adenine dinucleotide phosphate (NADPH) oxidoreductases, which correlates with cellular metabolic activity and the number of viable cells present. As shown in Figure 5A, staurosporine treatment for 24 hours reduced the cell viability dramatically.
RBC1023 co-treatment significantly rescued the loss of cell viability induced by staurosporine in NIH3T3 cells. We also performed ATP measurement by generating an ATP standard curve using Cell Titer-Glo ${ }^{\circledR}$ luminescent assay. As shown in Figure 5B, RBC1023 clearly restored the loss of ATP contents in cells treated with staurosporine. One-way ANOVA of the MTT and ATP assay data suggested that RBC1023 induces normalization or partial recovery of cell viability and ATP contents. Our results here further confirmed the cytoprotective effect of RBC1023 demonstrated by Cell Titer-Glo ${ }^{\circledast}$ assay.
A

NIH3T3 cells

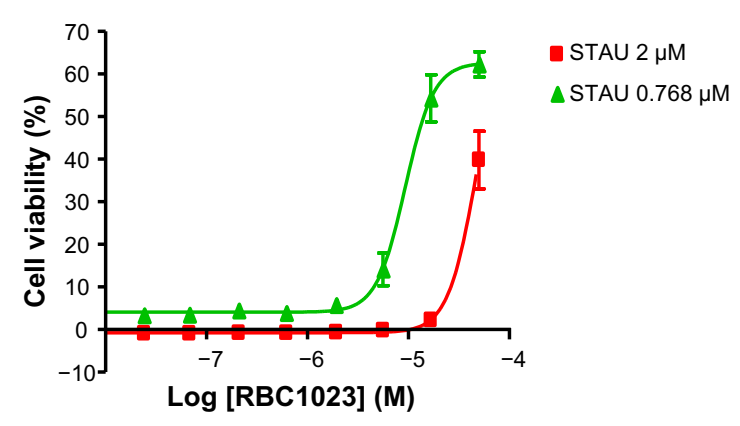

B

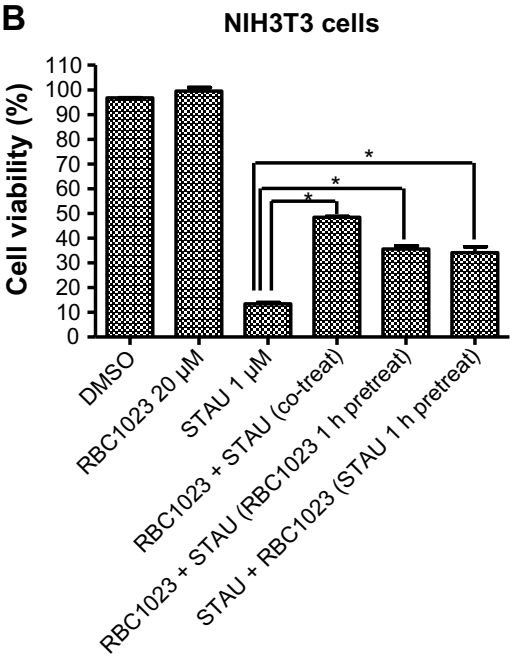

Figure 3 Dose-response protection and treatment timing study of RBCI023 against STAU-induced cell death in NIH3T3 cells.

Notes: (A) NIH3T3 cells were treated with a combination of various concentrations of RBCI023 (50 $\mu$ M to I $\mu$ M, three-fold dilution, ten doses) and STAU ( $0.768 \mu M$ or $2 \mu \mathrm{M}$ ) for 24 hours. (B) NIH3T3 cells were treated with DMSO; $20 \mu \mathrm{M}$ of RBCI023; I $\mu$ M of STAU; or $20 \mu \mathrm{M}$ of RBCI 023 and I $\mu$ M of staurosporine simultaneously; pretreated with $20 \mu \mathrm{M}$ of RBCI023 for I hour and then treated with I $\mu \mathrm{M}$ of staurosporine; or pretreated with I $\mu \mathrm{M}$ of staurosporine for I hour and then treated with $20 \mu \mathrm{M}$ of RBCl 023 . The cultures were then incubated for a total of 24 hours. The cell viability was measured by Cell Titer-Glo ${ }^{\circledR}$ assay (Promega Corporation, Fitchburg, WI, USA). $* P<0.0$ I (a highly significant difference between the indicated groups) by Student's $t$-test.

Abbreviations: DMSO, dimethyl sulfoxide; EC50, half maximal effective concentration; STAU, staurosporine. 


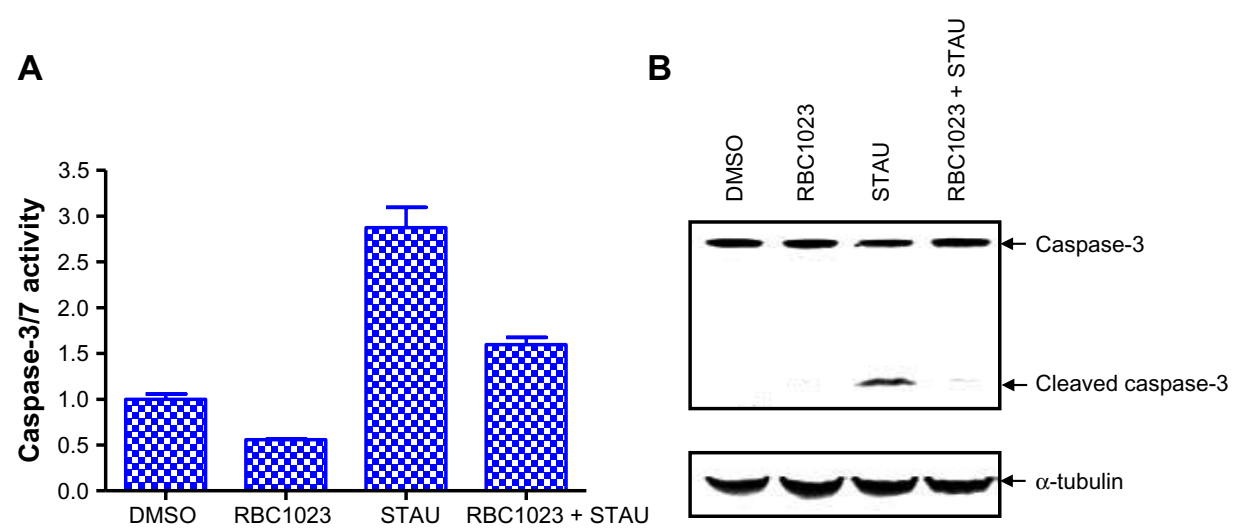

Figure 4 RBCI023 inhibits STAU-induced caspase-3 cleavage and activation in NIH3T3 cells.

Notes: NIH3T3 cells were treated with DMSO, $20 \mu \mathrm{M}$ of RBCI023, I $\mu \mathrm{M}$ of STAU, or $20 \mu \mathrm{M}$ of RBCI023 plus I $\mu$ M of STAU for 6 hours. Caspase activity was measured by Apo-ONE ${ }^{\circledast}$ Homogeneous Caspase-3/7 Assay (Promega Corporation, Fitchburg, WI, USA) (A), and processing of caspase-3 was detected by Western blotting with anticaspase-3 antibody (B). Positions of the intact and cleaved forms of capase-3 are indicated by arrows. $\alpha$-tubulin was used as a control for protein loading. One-way analysis of variance indicates: $P>0.05$ (DMSO versus [vs] RBCI023), $P>0.05$ (DMSO vs RBCI023 + STAU), and $P<0.01$ (STAU vs RBCI023 + STAU).

Abbreviations: DMSO, dimethyl sulfoxide; STAU, staurosporine.

\section{RBCI023 restores NIH3T3 cells from staurosporine-induced disruption of mitochondrial membrane potential}

Disruption of mitochondrial membrane potential $(\Delta \psi \mathrm{m})$, which is observed at an early stage of apoptosis in many cells, results in opening of the permeability transition pores (PTPs), causing a local disruption of the outer mitochondrial membrane. ${ }^{23,24}$ As a consequence, the soluble intermembrane proteins including cytochrome $\mathrm{c}$ are released, and these proteins contribute to the activation of caspases for chromatin condensation and DNA fragmentation. ${ }^{7}$ Based on this theory, we next assessed if $\mathrm{RBC} 1023$ restores NIH3T3 cells from staurosporine-induced loss of mitochondrial membrane potential. The mitochondrial membrane potential changes were measured by the cationic, lipophilic JC-10 dye. As shown in Figure 5C, NIH3 T3 cells that were treated with $1 \mu \mathrm{M}$ of staurosporine for 6 hours significantly lost mitochondrial membrane potential, whereas co-incubating the cells with RBC1023 and staurosporine apparently prevented staurosporine-induced mitochondrial membrane impairment. One-way ANOVA of the data also supports this statement. Our findings suggest that RBC1023 mediates mitochondrial protection in addition to its direct caspase inhibitory effect.

\section{Investigation of gene profile for the cytoprotective effect of RBCI023 by DNA microarray analysis}

To further explore the potential molecular mechanisms of the cytoprotection effect by RBC1023, we performed DNA
A

MTT assay

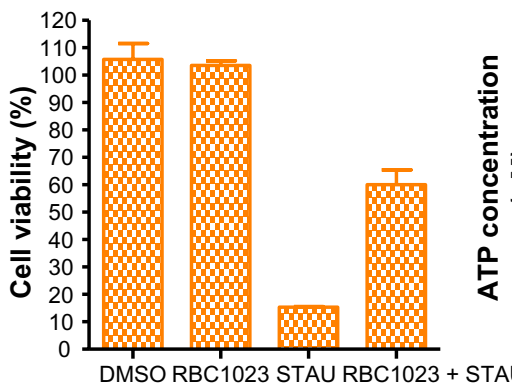

B

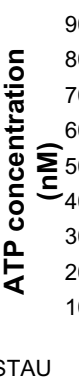

ATP assay

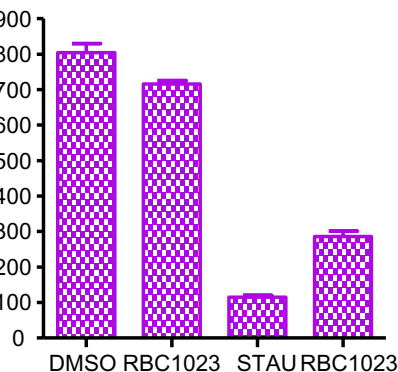

C

Mitochondrial $\Delta \psi m$ changes

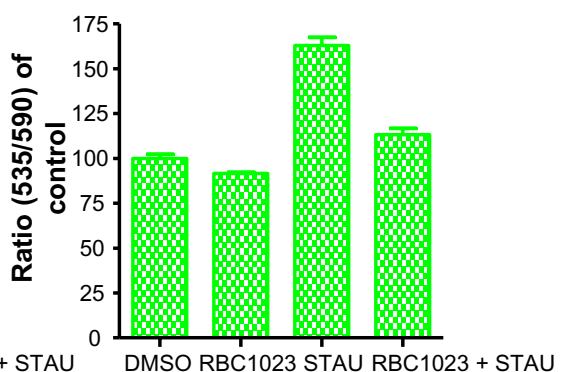

Figure 5 RBCI023 restores NIH3T3 cells from STAU-induced loss of cell viability, ATP contents, and disruption of mitochondrial membrane potential. Notes: NIH3T3 cells were treated with DMSO, $20 \mu \mathrm{M}$ of RBCI023, I $\mu \mathrm{M}$ of STAU, or $20 \mu \mathrm{M}$ of RBCI023 plus I $\mu$ M of STAU for 24 hours (A and B), or 6 hours (C). The cell viability was measured by MTT assay $(\mathbf{A})$ and ATP content assay (B), and the mitochondrial membrane potential was measured by JC-I0 mitochondrial membrane potential assay $(\mathbf{C})$. One-way analysis of variance indicates: (A) $P>0.05$ (DMSO versus [vs] RBCI023), $P<0.01$ (DMSO vs RBCI023 + STAU), and $P<0.01$ (STAU vs RBCI 023 + STAU); (B) $P<0.01$ (DMSO vs RBCI023), $P<0.00$ I (DMSO vs RBCI $023+\mathrm{STAU}$ ), and $\mathrm{P}<0.00 \mathrm{I}$ (STAU vs RBCI $023+\mathrm{STAU}$ ); (C) $P>0.05$ (DMSO vs RBCI023), $P>0.05$ (DMSO vs RBCI023 + STAU), and $P<0.001$ (STAU vs RBCI023 + STAU).

Abbreviations: ATP, adenosine triphosphate; DMSO, dimethyl sulfoxide; MTT, (3-(4,5-dimethylthiazol-2-yl)-2,5-diphenyltetrazolium bromide); STAU, staurosporine; $\Delta \psi$ m, mitochondrial membrane potential. 
microarray analysis using Affymetrix GeneChip Mouse Gene 1.0ST, which covers 26,166 coding transcripts. NIH3T3 cells were treated by one of four conditions as follows: DMSO, RBC1023, staurosporine, or RBC1023 plus staurosporine. For each condition, the NIH3T3 cells were exposed to the indicated treatment for 20 hours. RNA was harvested from the cells treated under each condition and then converted to cDNA, which was used to query the genes on the Affymetrix GeneChip Mouse Gene 1.0ST Array. The general microarray results showed that staurosporine treatment dramatically changes the global gene expression profiling, and the changes caused by treatment of staurosporine were significantly restored by the co-treatment of RBC1023 in NIH3T3 cells. The gene expressions between each group, analyzed using supervised clustering of the 200 upregulated and downregulated messenger (m)RNAs that exhibited the most significant differences in all groups, were determined by one-way ANOVA. As shown in the heat map (Figure 6), the control and RBC1023 alone treatment samples showed similar clustering of these specific gene expressions. However, there was a dramatic increase or decrease in the expression of many genes in the staurosporine treatment samples. Importantly, the expression levels of these downregulated or upregulated genes caused by treatment of staurosporine were significantly restored by the co-treatment of RBC1023 in NIH3T3 cells. Molecular functions of the top 200 up- and downregulated gene transcripts are listed in Table S1. The gene list includes some apoptosis and cellular signaling-related genes such as Htra2 (Omi), caspase-12, Etv1, Egr1, Nek7, Upkla, Skap2, and Tuba1b (Table S1). Furthermore, we summarized the top 50 genes upregulated (ranked by fold-change) in the RBC1023-plus-staurosporine treatment group in comparison with the staurosporine-alone treatment group, in which displays $\sim 2.5$ - to $\sim 4$.9-fold increases can be seen in Table 3. Interestingly, no known proapoptotic genes can be seen in this list (Table 3). We hypothesize that the upregulation of some cell survival genes may be partially responsible for the protective effect of $\mathrm{RBC} 1023$ against staurosporine-induced cell death.

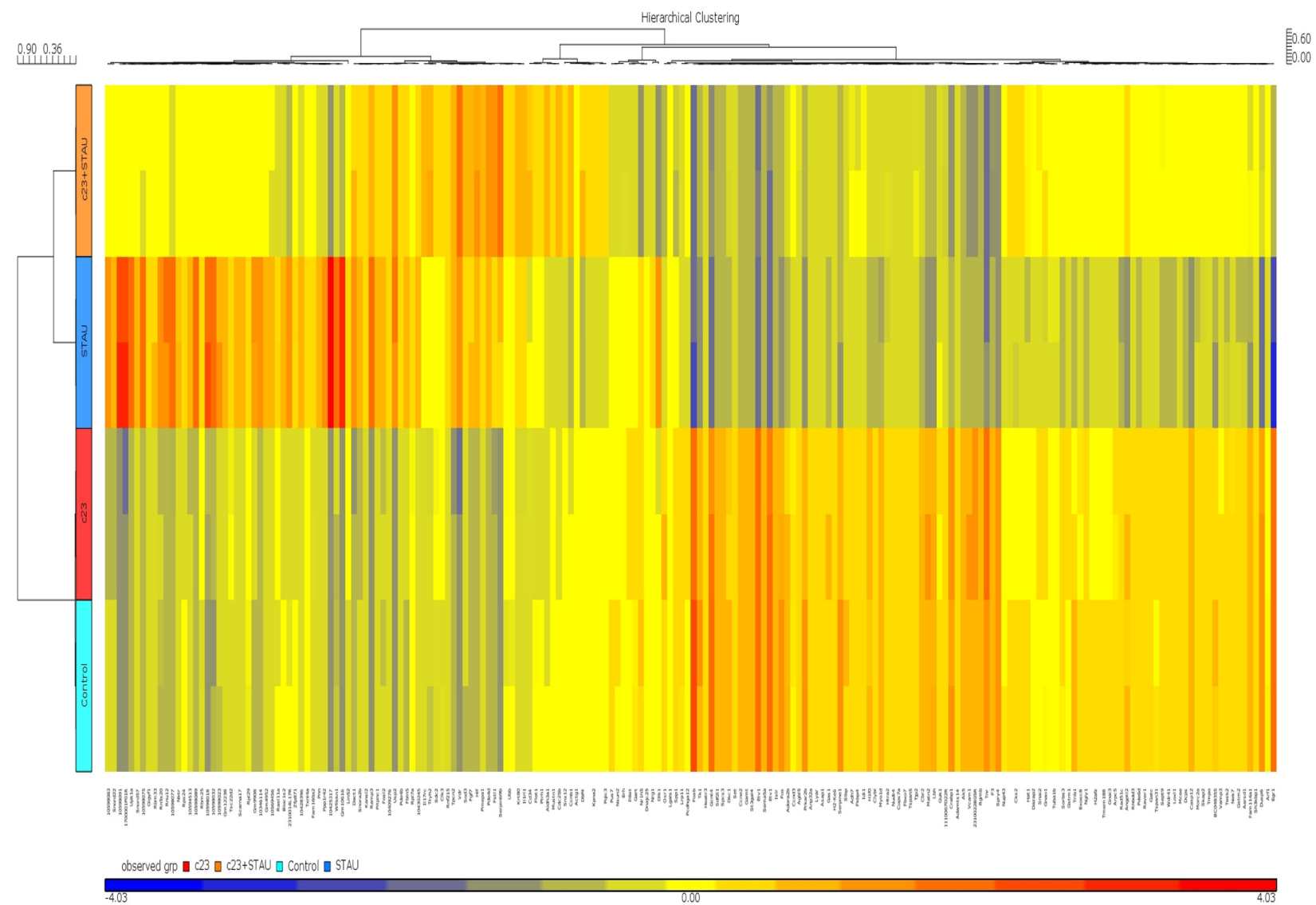

Figure 6 Hierarchical clustering of 200 upregulated and downregulated genes from NIH3T3 samples treated with DMSO, RBCI023, STAU, or RBCI023 plus STAU. Notes: NIH3T3 cells were treated with DMSO, $20 \mu$ M of RBCI023 (c23), I $\mu$ M of STAU, or $20 \mu M$ of RBCI023 (c23) plus I $\mu$ M of STAU for 20 hours. Total RNA was isolated and converted to complementaryDNA by reverse transcriptase reaction. The cDNA products were fragmented and hybridized to Affymetrix GeneChip Mouse Gene I.OST (Affymetrix Inc., Santa Clara, CA, USA). ${ }^{15}$ Clustering of 200 upregulated and downregulated genes that exhibit significant differences in all groups was determined by one-way analysis of variance. The clustering was based on fold changes within each paired data set. The color scale of the log2 ratios is shown at the bottom. Abbreviations: DMSO, dimethyl sulfoxide; STAU, staurosporine. 
Table 3 Top 50 genes upregulated (RBC1023 + STAU group versus STAU group)

\begin{tabular}{|c|c|c|c|}
\hline Gene symbol & $\begin{array}{l}\text { Fold-change (RBCI } 023+ \\
\text { STAU vs STAU) }\end{array}$ & $\begin{array}{l}P \text {-value (RBCI } 023+ \\
\text { STAU vs STAU) }\end{array}$ & Function \\
\hline Ly6a & 4.94653 & $5.35 \mathrm{E}-06$ & Lymphocyte antigen 6 complex \\
\hline Lrrn4cl & 4.09678 & 2.17E-05 & Function unknown \\
\hline Egrl & 4.0647 & 4.13E-05 & Differentiation and mitogenesis \\
\hline Plat & 3.90703 & 0.00025859 & Plasminogen activator \\
\hline Bdkrbl & 3.89931 & 2.63E-06 & Inflammatory responses \\
\hline Rhob & 3.5974 & 0.000108495 & Ras signaling cascade \\
\hline Nek2 & 3.42607 & $6.47 \mathrm{E}-06$ & $\begin{array}{l}\text { Serine/threonine-protein kinase that is involved in mitotic } \\
\text { regulation }\end{array}$ \\
\hline Serpinbla & 3.41146 & $3.16 \mathrm{E}-05$ & Regulates the activity of the neutrophil proteases elastase \\
\hline Taok I & 3.35134 & 0.00379721 & Serine/threonine-protein kinase \\
\hline Bhlhe40 & 3.29921 & 0.000687826 & Cell differentiation \\
\hline Angpt/2 & 3.28147 & $6.37 \mathrm{E}-05$ & Growth factors \\
\hline 4930547N/6Rik & 3.24155 & $7.27 \mathrm{E}-06$ & Function unknown \\
\hline Plxna2 & 3.20986 & $3.55 \mathrm{E}-06$ & Nervous system development \\
\hline Aurka & 3.17042 & 0.00014278 & Serine/threonine-protein kinase 6 \\
\hline Tceall & 3.14666 & I.88E-05 & Transcriptional regulation \\
\hline 1118 & 3.07789 & $8.13 \mathrm{E}-05$ & A proinflammatory cytokine \\
\hline Tacr2 & 3.04967 & $5.85 \mathrm{E}-05$ & Receptors for tachykinins \\
\hline Canbl & 3.00447 & I.19E-05 & Control of the cell cycle at the $\mathrm{G} 2 / \mathrm{M}$ (mitosis) transition \\
\hline Hist /h/c & 2.9718 & $2.15 \mathrm{E}-05$ & $\begin{array}{l}\text { Chromatin remodeling, nucleosome spacing and DNA } \\
\text { methylation }\end{array}$ \\
\hline Mfsd6 & 2.96238 & 4.17E-06 & Function unknown \\
\hline Cdc25c & 2.95929 & 8.77E-06 & Cell mitotic control \\
\hline Arhgef 12 & 2.94683 & 0.00060089 & Stimulate Rho-dependent signals \\
\hline Tnfaip6 & 2.92751 & $2.48 \mathrm{E}-05$ & Involved in cell-cell and cell-matrix interactions \\
\hline Depdcla & 2.92024 & $5.13 \mathrm{E}-05$ & Transcriptional regulation \\
\hline Cep55 & 2.83691 & $4.68 \mathrm{E}-06$ & Mitotic exit and cytokinesis \\
\hline Gas 213 & 2.81642 & $8.16 \mathrm{E}-07$ & $\begin{array}{l}\text { Promote and stabilize the formation of the actin and } \\
\text { microtubule network }\end{array}$ \\
\hline Ttll7 & 2.80163 & 3.77E-05 & Neurite growth \\
\hline Mastl & 2.79123 & $3.1 \mathrm{IE}-06$ & A regulator of mitosis entry and maintenance \\
\hline Cdkn3 & 2.75997 & $4.81 \mathrm{E}-06$ & Cell cycle regulation \\
\hline Kif2c & 2.73935 & $4.82 \mathrm{E}-05$ & Regulates the turnover of microtubules during mitosis \\
\hline Anxa8 & 2.72379 & 0.000119099 & Involved in the blood coagulation cascade \\
\hline Cyp39al & 2.71735 & $9.70 \mathrm{E}-06$ & $\begin{array}{l}\text { Involved in drug metabolism and synthesis of cholesterol, } \\
\text { steroids }\end{array}$ \\
\hline Bend6 & 2.69474 & 0.000311133 & Function unknown \\
\hline Hyls I & 2.69324 & I.54E-06 & Required for the formation of cilia \\
\hline 6720463M24Rik & 2.66567 & $7.35 \mathrm{E}-06$ & Function unknown \\
\hline Cenpe & 2.65857 & 8.09E-07 & Essential for the maintenance of chromosomal stability \\
\hline AdamtsI5 & 2.65327 & $2.33 \mathrm{E}-06$ & Function unknown \\
\hline TIr 4 & 2.64933 & $4.06 \mathrm{E}-05$ & Mediate the innate immune response to LPS \\
\hline Dusp6 & 2.61857 & 0.000175186 & Inactivates MAP kinases \\
\hline Kif20b & 2.60411 & 0.000105112 & Required for completion of cytokinesis \\
\hline Stxbp4 & 2.60053 & 0.0106744 & Plays a role in the translocation of transport vesicles \\
\hline Aldh3al & 2.59577 & $5.93 \mathrm{E}-05$ & $\begin{array}{l}\text { The metabolism of corticosteroids, biogenic amines, } \\
\text { neurotransmitters, and lipid }\end{array}$ \\
\hline Prcl & $2.5887 \mid$ & $1.85 \mathrm{E}-05$ & Involved in cytokinesis \\
\hline Ndc80 & 2.58587 & $0.000245 \mid 2 I$ & $\begin{array}{l}\text { Required for chromosome segregation and spindle } \\
\text { checkpoint activity }\end{array}$ \\
\hline Glmn & 2.58467 & 0.00018307 & Essential for normal development of the vasculature \\
\hline Plk & 2.54604 & $2.2 \mathrm{IE}-05$ & $\begin{array}{l}\text { Regulators of cell cycle progression, mitosis, cytokinesis, } \\
\text { and the DNA damage }\end{array}$ \\
\hline Atf7ip2 & 2.54547 & I.85E-05 & Modulates transcription regulation and chromatin formation \\
\hline Mir $15 b$ & $2.5367 \mid$ & 0.00251676 & Involved in post-transcriptional regulation of gene expression \\
\hline Suox & 2.53666 & $9.13 \mathrm{E}-05$ & Catalyzes the oxidation of sulfite to sulfate \\
\hline Serpinb9b & 2.53635 & $0.000|23| 4 \mid$ & Inhibits the activity of the effector molecule granzyme \\
\hline
\end{tabular}

Abbreviation: STAU, staurosporine. 


\section{Discussion}

In this study, we identified 19 caspase inhibitors that showed cytoprotection against staurosporine-induced cell death by screening Bionet's 37,500-compound library against caspase-1, -3 , and -9 , and then through multiselective processes. $\mathrm{RBC} 1023$, a selective caspase- 3 inhibitor, showed dose-dependent cytoprotection against staurosporine-induced cell death in different types of cell lines. We also confirmed that RBC1023 protects NIH3T3 cells from the staurosporineinduced caspase- 3 cleavage and activation. These results indicate that reduced apoptotic cell death and increased cell proliferation are attributed to the inhibition of caspase activation by $\mathrm{RBC} 1023$. Interestingly, $\mathrm{RBC} 1023$ protected against cell death even up to 1 hour after staurosporine treatment.

Mitochondria play a central role in apoptosis, ${ }^{25}$ and there are reports that demonstrate the critical role of mitochondria in cytoprotection. ${ }^{26,27}$ We evaluated the possible correlation between the protection by $\mathrm{RBC} 1023$ and the mitochondrial function. First, our MTT assay results demonstrated that $\mathrm{RBC} 1023$ co-treatment was able to rescue the staurosporinetriggered loss of cell viability, suggesting RBC1023 restored the loss of the enzyme activity in mitochondria that reduces MTT during staurosporine treatment. Secondly, we found that co-treatment with $\mathrm{RBC} 1023$ and staurosporine resulted in a significant increase of cellular ATP content in comparison with the staurosporine treatment group. Our results suggest that $\mathrm{RBC} 1023$ restored the loss of ATP production during the staurosporine treatment. Furthermore, our results indicated that $\mathrm{RBC} 1023$ restored staurosporine-induced disruption of mitochondrial membrane potential. It is well known that mitochondrial dysfunction is the primary cause of staurosporineinduced apoptosis. A critical factor mediating mitochondrial dysfunction is the opening of mitochondrial PTP (mPTP). The opening of the MPTP can lead to a bioenergetic, biosynthetic, and redox crisis in a cell that can directly threaten the survival of the cell. ${ }^{28}$ When the mPTP is open, the mitochondrial inner membrane becomes permeable to protons, which then lead to the uncoupling of the electron respiratory chain and the collapse of membrane potential, which in turn leads to a cessation of ATP generation in mitochondria. ${ }^{28,29}$ In the $\mathrm{RBC} 1023-$ pretreated NIH3T3 cells, the staurosporine-induced loss of mitochondrial membrane potential and decline in ATP levels was alleviated, supporting the notion that the cytoprotection of $\mathrm{RBC} 1023$ is, in part, due to the prevention of mitochondrial dysfunction. Upon activation of mPTP, functional breakdown and morphological disintegration of mitochondria occur, thus initiating cell death. ${ }^{30}$ Another threatening consequence of the altered mitochondrial permeability is the release of apoptogenic proteins from the mitochondrial inter-membrane space into the cytosol. ${ }^{28,29}$ Cytochrome $\mathrm{c}$ is associated with the inner mitochondrial membrane and serves as an essential component of the electron transfer chain. With opening of the MPTP and translocation of cytochrome c into the cytosol, mitochondrial function is compromised. However, in this study, the release of cytochrome $\mathrm{c}$ from the mitochondrial matrix into the cytosol by staurosporine was not significantly inhibited by RBC1023 (data not shown). This was possibly because caspase- 3 is activated downstream of cytochrome $\mathrm{c}$ release and apoptosome formation in the mitochondrial pathway. It has been reported that B-cell lymphoma 2 protects endothelial cells against gamma radiation-induced caspase activation via a Raf-MEK-ERK cell survival signaling pathway that is independent of cytochrome c release.$^{31} \mathrm{It}$ is possible that RBC1023 also exerts its cytoprotective effect via some cell survival signaling pathways that are independent of the mechanism of the blockage of cytochrome $\mathrm{c}$ release Taken together, we conclude that $\mathrm{RBC} 1023$, in addition to its direct caspase inhibitory effect, has some mitochondrial protective effect, which is at least partially responsible for its cytoprotection. For our next study, the mitochondrial oxygen consumption will be measured to directly evaluate mitochondrial function and cellular respiratory activity. Whether $\mathrm{RBC1023's} \mathrm{mitochondrial} \mathrm{protective} \mathrm{effect} \mathrm{is} \mathrm{related} \mathrm{to} \mathrm{its}$ caspase inhibitory effect could be an interesting subject for future study.

The DNA microarray analysis in the present study demonstrates that $\mathrm{RBC} 1023$ can recover the loss of expression of many genes induced by staurosporine treatment, correlating with its cytoprotection. The top 50 genes that were upregulated in the RBC1023-plus-staurosporine treatment group compared to the staurosporine-alone treatment group include several functional categories, such as cell differentiation and growth genes (Egr1, Bhlhe40, and Angptl2), cell cycle regulation genes (Ccnb1, Cdc25c, Cep55, Mastl, Cdkn3, Kif2c, and Plk1), cellular signaling genes (Rhob, Nek2, Taok1, Aurka, and Arhgef12), and transcription regulation genes (Tceal1, Depdc1a, and Atf7ip2), all of which are mainly responsible for cell growth and differentiation. While further studies need to be done to verify the roles of these genes by real time-quantitative polymerase chain reaction and/or Western blot, our current findings clearly suggest that upregulation of these pro-growth and pro-survival genes by $\mathrm{RBC} 1023$ plays a critical role in its cytoprotective effect.

RBC1023 is a selective, reversible, small-molecule caspase-3 inhibitor, which has multiple advantages compared to the known caspase inhibitors that are being developed. For 
example, the caspase inhibitors from Pfizer's IDN6556 series (Pfizer, Inc., New York, NY, USA) ${ }^{32}$ and Vertex's 166 series (Vertex Pharmaceuticals, Boston, MA USA) ${ }^{33}$ are irreversible, peptide-mimic and Pan-caspase inhibitors. Merck's caspase-3 inhibitor M867 (Merck \& Co., Inc., White House Station, NJ, USA) is selective and reversible, but a peptide mimic. ${ }^{34,35}$ Modified peptides generally do not make good therapeutic reagents, due to problems such as proteolysis and poor cellular permeability; ${ }^{36}$ therefore, selective small-molecule caspase inhibitors offer significant potential for protection of numerous cell types. Indeed, our preliminary results have shown that RBC1023 protects primary normal human oral keratinocytes from radiation-induced cell death using radiation colony formation assay (data not shown). During head and neck cancer therapy, oral mucositis caused by normal (nonmalignant) cell apoptosis is recognized as a major side effect of the therapy. Therefore, the potential use of cytoprotectants, such as the caspase inhibitors, for prevention of severe mucositis during head and neck cancer therapy could present a unique opportunity for effective therapy. In addition, caspases have also been demonstrated to be involved in some non-apoptotic functions, such as the regulatory events that are important for neural functions including axon pruning and synapse elimination, which are necessary to refine mature neuronal circuits. ${ }^{37}$ Small-molecule caspase inhibitor drugs may therefore have potential therapeutic or preventive efficacies against neurodegenerative diseases.

\section{Conclusion}

Taken together, our experimental study results indicate that RBC1023 protects NIH3T3 cells against staurosporineinduced apoptosis via inhibiting caspase activity, restoring mitochondrial membrane potential, and possibly upregulating some cell survival-related gene expressions.

\section{Acknowledgments}

We gratefully acknowledge Drs Kurumi Horiuchi and Yuan Wang for their early works in this project; Mr John Tobias from the Molecular Profiling Facility at University of Pennsylvania School of Medicine for performing the DNA microarray analysis; and Dr Honglin Zhou at University of Pennsylvania School of Medicine for providing the SHSY-5Y cell line and conducting the cell viability assay of SHSY-5Y cells in his lab. This work was partially supported by NIH Small Business Innovation Research grants 5R44DE017485 and 5R44CA140166 to HM.

\section{Disclosure}

The authors report no conflicts of interest in this work.

\section{References}

1. Pop C, Salvesen GS. Human caspases: activation, specificity, and regulation. J Biol Chem. 2009;284(33):21777-21781.

2. Cohen GM. Caspases: the executioners of apoptosis. Biochem J. 1997;326(Pt 1):1-16.

3. Nicholson DW, Thornberry NA. Caspases: killer proteases. Trends Biochem Sci. 1997;22(8):299-306.

4. Salvesen GS, Dixit VM. Caspases: intracellular signaling by proteolysis. Cell. 1997;91(4):443-446.

5. Nagata S. Apoptosis by death factor. Cell. 1997;88(3):355-365.

6. Green DR, Reed JC. Mitochondria and apoptosis. Science. 1998;281(5381):1309-1312.

7. Susin SA, Lorenzo HK, Zamzami N, et al. Molecular characterization of mitochondrial apoptosis-inducing factor. Nature. 1999;397(6718): 441-446.

8. McBride CB, McPhail LT, Vanderluit JL, Tetzlaff W, Steeves JD. Caspase inhibition attenuates transection-induced oligodendrocyte apoptosis in the developing chick spinal cord. Mol Cell Neurosci. 2003;23(3):383-397.

9. Papaconstantinou HT, Xie C, Zhang W, et al. The role of caspases in methotrexate-induced gastrointestinal toxicity. Surgery. 2001;130(5): 859-865.

10. Lee ER, Kim JH, Choi HY, Jeon K, Cho SG. Cytoprotective effect of eriodictyol in UV-irradiated keratinocytes via phosphatase-dependent modulation of both the $\mathrm{p} 38$ MAPK and Akt signaling pathways. Cell Physiol Biochem. 2011;27(5):513-524.

11. Park K, Lee JH. Protective effects of resveratrol on UVB-irradiated $\mathrm{HaCaT}$ cells through attenuation of the caspase pathway. Oncol Rep. 2008;19(2):413-417.

12. Pauloin T, Dutot M, Joly F, Warnet JM, Rat P. High molecular weight hyaluronan decreases UVB-induced apoptosis and inflammation in human epithelial corneal cells. Mol Vis. 2009;15:577-583.

13. Rass K, Reichrath J. UV damage and DNA repair in malignant melanoma and nonmelanoma skin cancer. Adv Exp Med Biol. 2008;624: $162-178$.

14. Smaili S, Hirata H, Ureshino R, et al. Calcium and cell death signaling in neurodegeneration and aging. An Acad Bras Cienc. 2009;81(3): 467-475.

15. GeneChip ${ }^{\circledR}$ expression analysis: data analysis fundamentals [technical manual]. Sanra Clara, CA: Affymetrix Inc; 2004.

16. Zhang JH, Chung TD, Oldenburg KR. A simple statistical parameter for use in evaluation and validation of high throughput screening assays. J Biomol Screen. 1999;4(2):67-73.

17. Okun I, Malarchuk S, Dubrovskaya E, et al. Screening for caspase-3 inhibitors: effect of a reducing agent on identified hit chemotypes. J Biomol Screen. 2006;11(6):694-703.

18. Tamaoki T, Nomoto H, Takahashi I, Kato Y, Morimoto M, Tomita F. Staurosporine, a potent inhibitor of phospholipid/Ca++ dependent protein kinase. Biochem Biophys Res Commun. 1986;135(2): 397-402.

19. Rüegg UT, Burgess GM. Staurosporine, K-252 and UCN-01: potent but nonspecific inhibitors of protein kinases. Trends Pharmacol Sci. 1989;10(6):218-220.

20. Belmokhtar CA, Torriglia A, Counis MF, Courtois Y, JacqueminSablon A, Ségal-Bendirdjian E. Nuclear translocation of a leukocyte elastase Inhibitor/Elastase complex during staurosporine-induced apoptosis: role in the generation of nuclear L-DNase II activity. Exp Cell Res. 2000;254(1):99-109.

21. Yuste VJ, Sánchez-López I, Solé C, et al. The contribution of apoptosis-inducing factor, caspase-activated DNase, and inhibitor of caspase-activated DNase to the nuclear phenotype and DNA degradation during apoptosis. J Biol Chem. 2005;280(42): 35670-35683.

22. Smaili SS, Hsu YT, Sanders KM, Russell JT, Youle RJ. Bax translocation to mitochondria subsequent to a rapid loss of mitochondrial membrane potential. Cell Death Differ. 2001;8(9):909-920. 
23. Petit PX, Lecoeur H, Zorn E, Dauguet C, Mignotte B, Gougeon ML. Alterations in mitochondrial structure and function are early events of dexamethasone-induced thymocyte apoptosis. J Cell Biol. 1995;130(1):157-167.

24. Zamzami N, Marchetti P, Castedo M, et al. Sequential reduction of mitochondrial transmembrane potential and generation of reactive oxygen species in early programmed cell death. J Exp Med. 1995;182(2):367-377.

25. Wang X. The expanding role of mitochondria in apoptosis. Genes Dev. 2001;15(22):2922-2933.

26. Karachitos A, García Del Pozo JS, de Groot PW, Kmita H, Jordán J. Minocycline mediated mitochondrial cytoprotection: premises for therapy of cerebrovascular and neurodegenerative diseases. Curr Drug Targets. 2013;14(1):47-55.

27. Brenner C, Ventura-Clapier R, Jacotot E. Mitochondria and cytoprotection. Biochem Res Int. 2012;2012:351264.

28. Armstrong JS. The role of the mitochondrial permeability transition in cell death. Mitochondrion. 2006;6(5):225-234.

29. Galluzzi L, Morselli E, Kepp O, Kroemer G. Targeting post-mitochondrial effectors of apoptosis for neuroprotection. Biochim Biophys Acta. 2009;1787(5):402-413.

30. Kristián T. Metabolic stages, mitochondria and calcium in hypoxic/ischemic brain damage. Cell Calcium. 2004;36(3-4): 221-233.
31. Kumar P, Coltas IK, Kumar B, Chepeha DB, Bradford CR, Polverini PJ. Bcl-2 protects endothelial cells against gamma-radiation via a Raf-MEK-ERK-survivin signaling pathway that is independent of cytochrome c release. Cancer Res. 2007;67(3):1193-1202.

32. Hoglen NC, Chen LS, Fisher CD, Hirakawa BP, Groessl T, Contreras PC. Characterization of IDN-6556 (3-[2-(2-tert-butyl-phenylaminooxalyl)amino]-propionylamino]-4-oxo-5-(2,3,5,6-tetrafluoro-phenoxy)pentanoic acid): a liver-targeted caspase inhibitor. J Pharmacol Exp Ther. 2004;309(2):634-640.

33. Weber P, Wang P, Maddens S, et al. VX-166: a novel potent small molecule caspase inhibitor as a potential therapy for sepsis. Crit Care. 2009;13(5):R146.

34. Méthot N, Huang J, Coulombe N, et al. Differential efficacy of caspase inhibitors on apoptosis markers during sepsis in rats and implication for fractional inhibition requirements for therapeutics. $J$ Exp Med. 2004;199(2):199-207.

35. Kim KW, Moretti L, Lu B. M867, a novel selective inhibitor of caspase-3 enhances cell death and extends tumor growth delay in irradiated lung cancer models. PLoS One. 2008;3(5):e2275.

36. Callus BA, Vaux DL. Caspase inhibitors: viral, cellular and chemical. Cell Death Differ. 2007;14(1):73-78.

37. Hyman BT, Yuan J. Apoptotic and non-apoptotic roles of caspases in neuronal physiology and pathophysiology. Nat Rev Neurosci. 2012;13(6):395-406. 


\section{Supplementary material}

Table SI Molecular functions of the top 200 upregulated and downregulated clustering genes in the heat map

\begin{tabular}{|c|c|c|c|}
\hline Ref seq & Gene symbol & $\begin{array}{l}P \text {-value (observed } \\
\text { group) }\end{array}$ & Molecular function \\
\hline I. NM_0I0655 & Kpna2 & $5.05 \mathrm{E}-08$ & Nuclear protein import \\
\hline 2. NM_I73752 & I/ I0067D22Rik & $6.85 \mathrm{E}-08$ & Function unknown \\
\hline 3. NM_0254I5 & Cks2 & 2.15E-07 & Binds to cyclin dependent kinases \\
\hline 4. NM_0I0655 & Kpna2 & $2.90 \mathrm{E}-07$ & Nuclear protein import \\
\hline 5. NM_00I08II27 & Adamts 14 & $5.96 \mathrm{E}-07$ & Metallopeptidase \\
\hline 6. NM_007960 & Etvl & 6.49E-07 & Transcriptional activator \\
\hline 7. NM_0I9752 & Htra2 & $8.23 \mathrm{E}-07$ & Caspase activation \\
\hline 8. NM_I75|49 & 2310022B05Rik & $9.86 \mathrm{E}-07$ & Function unknown \\
\hline 9. NM_0III58 & Prkar2b & I.19E-06 & cAMP signaling \\
\hline I0. NM_029074 & Tmem / 88 & I.44E-06 & Protein phosphatase \\
\hline II. - & & $1.52 \mathrm{E}-06$ & $N / A$ \\
\hline 12. NM_028607 & Blocls2 & I.57E-06 & Biogenesis of lysosome \\
\hline I3. NM_0I0358 & Gstm I & 2.17E-06 & Glutathione S-transferases \\
\hline I4. NM_I72757 & Heatr3 & $2.5 \mathrm{IE}-06$ & Function unknown \\
\hline 15. NM_008036 & Fosb & $3.03 \mathrm{E}-06$ & Form the transcription factor complex AP-I \\
\hline 16. NM_I45692 & Ppplr42 & $3.03 \mathrm{E}-06$ & Regulates phosphatase activity \\
\hline 17. NM_009178 & St3gal4 & $3.24 \mathrm{E}-06$ & Protein glycosylation \\
\hline 18. NM_I98092 & Usp2 & $3.36 \mathrm{E}-06$ & $\begin{array}{l}\text { Hydrolase that deubiquitinates polyubiquitinated target } \\
\text { proteins }\end{array}$ \\
\hline 19. ENSMUST0000000000 I & Gnai3 & $3.69 \mathrm{E}-06$ & Modulator in various transmembrane signaling systems \\
\hline 20. NM_0I3496 & Crabpl & $3.79 \mathrm{E}-06$ & $\begin{array}{l}\text { Involved in retinoic acid-mediated differentiation and } \\
\text { proliferation processes }\end{array}$ \\
\hline 21. - & & 4.39E-06 & $\mathrm{N} / \mathrm{A}$ \\
\hline 22. NM_022995 & Pmepal & $4.56 \mathrm{E}-06$ & Involved in down-regulation of the androgen receptor \\
\hline 23. NM_00I048I92 & Agbl5 & 4.73E-06 & Mediates tubulin deglutamylation \\
\hline 24. NM_0II654 & Tubalb & $4.92 \mathrm{E}-06$ & Interaction with PI3KRI \\
\hline 25. NM_029556 & Clybl & 4.95E-06 & Citrate lyase \\
\hline 26. NM_I78942 & III 7rc & 4.99E-06 & Cytokine signaling \\
\hline 27. NM_008495 & Lgals I & $5.13 \mathrm{E}-06$ & Regulates cell proliferation \\
\hline 28. NM_009672 & Anp32a & $5.18 \mathrm{E}-06$ & Cell proliferation and differentiation \\
\hline 29. NM_033595 & Pcdhgal 2 & $5.32 \mathrm{E}-06$ & $\begin{array}{l}\text { Involved in the establishment and maintenance of specific } \\
\text { neuronal connections in the brain }\end{array}$ \\
\hline 30. NM_00795I & Erh & $5.36 \mathrm{E}-06$ & $\begin{array}{l}\text { Involved in the establishment of specific neuronal connections } \\
\text { in the brain }\end{array}$ \\
\hline 31. ENSMUST00000066352 & Ptrhl & 5.47E-06 & tRNA hydrolase \\
\hline 32. NM_010918 & Nktr & $5.68 \mathrm{E}-06$ & Involved in the function of NK cells \\
\hline 33. NM_0I3726 & Dbf4 & 5.8IE-06 & Plays a central role in DNA replication and cell proliferation \\
\hline 34. NM_03I408 & Gigyfl & $5.85 \mathrm{E}-06$ & Regulates tyrosine kinase receptor signaling \\
\hline 35. NM_0II056 & Pde4d & $5.86 \mathrm{E}-06$ & Degrade cAMP \\
\hline 36. ENSMUST00000029316 & Exosc8 & $6.09 \mathrm{E}-06$ & Participates in cellular RNA processing and degradation events \\
\hline 37. NM_0I95II & Ramp3 & $6.55 \mathrm{E}-06$ & Receptor for adrenomedullin \\
\hline 38. NR_0338I3 & DlkI & $6.72 \mathrm{E}-06$ & Plays a role in neuroendocrine differentiation \\
\hline 39. - & & $6.73 \mathrm{E}-06$ & $\mathrm{~N} / \mathrm{A}$ \\
\hline 40. NM_0I2043 & Islr & $6.93 \mathrm{E}-06$ & Function unknown \\
\hline 4I. NM_027030 & Dcps & 7.14E-06 & Decapping scavenger enzyme \\
\hline 42. - & & $7.55 \mathrm{E}-06$ & $\mathrm{~N} / \mathrm{A}$ \\
\hline 43. NM_I72574 & Pqlc3 & 7.74E-06 & Protein coding \\
\hline 44. NM_0254I5 & Cks2 & $8.20 \mathrm{E}-06$ & Involved in cyclin dependent kinase function \\
\hline 45. NM_0I0I7I & F3 & $8.68 \mathrm{E}-06$ & Coagulation factor III \\
\hline 46. NM_026268 & Dusp6 & 8.95E-06 & Inactivates MAP kinases \\
\hline 47. NM_016762 & Matn2 & $9.13 \mathrm{E}-06$ & Formation of filamentous networks \\
\hline 48. NM_I44829 & Aarsd I & I.0IE-05 & tRNA synthetase \\
\hline 49. - & & I.04E-05 & $\mathrm{N} / \mathrm{A}$ \\
\hline 50. NM_027859 & $\operatorname{Rnf215}$ & I.05E-05 & Ring finger protein \\
\hline
\end{tabular}


Table SI (Continued)

\begin{tabular}{|c|c|c|c|}
\hline Ref seq & Gene symbol & $\begin{array}{l}P \text {-value (observed } \\
\text { group) }\end{array}$ & Molecular function \\
\hline 5I. NM_009154 & Sema5a & I.05E-05 & Involved in axonal guidance during neural development \\
\hline 52. NM_001033165 & Dnajc25 & I.07E-05 & Function unknown \\
\hline 53. NM_007476 & Arfl & I.I9E-05 & Vesicular trafficking \\
\hline 54. NM_02970I & Spcs3 & I.2IE-05 & Removes signal peptides from nascent proteins \\
\hline 55. AKI39984 & Gm 10616 & I.2IE-05 & $\mathrm{N} / \mathrm{A}$ \\
\hline 56. NM_026815 & Upkla & I.22E-05 & Mediates signal transduction events \\
\hline 57. NM_I72563 & Hlf & $1.22 \mathrm{E}-05$ & Function unknown \\
\hline 58. NM_009193 & SIbp & $1.28 \mathrm{E}-05$ & Involved in the histone pre-mRNA processing \\
\hline 59. NM_007960 & Etvl & $1.28 \mathrm{E}-05$ & Transcriptional activator \\
\hline 60. NM_001081636 & Cond3 & I.29E-05 & Cell cycle regulation \\
\hline 61. NM_028770 & Krt80 & I.30E-05 & Major structural fibers of cells \\
\hline 62. NM_0I6750 & H2afz & I.3IE-05 & Nucleosome structure protein \\
\hline 63. - & & I.37E-05 & N/A \\
\hline 64. NM_0II366 & Sorbs3 & I.39E-05 & Activation of JNK \\
\hline 65. NR_028560 & Scarnal 7 & I.4IE-05 & Function unknown \\
\hline 66. NR_028560 & Scarnal 7 & I.4IE-05 & Function unknown \\
\hline 67. NM_008008 & Fgf7 & I.42E-05 & $\begin{array}{l}\text { Regulation of embryonic development, cell proliferation and } \\
\text { cell differentiation }\end{array}$ \\
\hline 68. NM_0279II & Raverl & I.44E-05 & Modulate regulated alternative splicing events \\
\hline 69. NM_019840 & Pde4b & I.44E-05 & Hydrolyzes CAMP \\
\hline 70. NM_0II873 & Dazap2 & I.46E-05 & Cell signaling and transcription regulation \\
\hline 7I. NM_025982 & Tspan3I & I.46E-05 & Regulation of cell development, activation, growth and motility \\
\hline 72. NM_010655 & Kpna2 & I.50E-05 & Nuclear protein import \\
\hline 73. NM_00889I & Pnn & I.50E-05 & Transcriptional activator \\
\hline 74. NM_008193 & Gukl & I.5IE-05 & Essential for recycling GMP \\
\hline 75. NM_198658 & Nrlh5 & I.54E-05 & Function unknown \\
\hline 76. NM_00I242364 & Fam $160 a 2$ & I.56E-05 & Promotes vesicle trafficking \\
\hline 77. NM_021605 & Nek7 & I.60E-05 & Mitotic cell cycle progression \\
\hline 78. NM_009387 & $T k I$ & I.62E-05 & Thymidine kinase \\
\hline 79. NM_02528I & Lyar & I.64E-05 & Function unknown \\
\hline 80. NM_I72458 & $Z f p 87 I$ & I.64E-05 & Function unknown \\
\hline 81. NM_I77390 & Myold & I.68E-05 & Involved in intracellular movements \\
\hline 82. NM_I53195 & Fbxo7 & I.7IE-05 & A negative regulator of NF-kappaB signaling \\
\hline 83. NM_I44549 & Tribl & I.77E-05 & $\begin{array}{l}\text { Interacts with MAPK kinases and regulates activation of MAP } \\
\text { kinases }\end{array}$ \\
\hline 84. NM_023II7 & $C d c 25 b$ & I.80E-05 & Dephosphorylates CDKI and stimulates its kinase activity \\
\hline 85. NR_028480 & $G m / 2238$ & I.84E-05 & Function unknown \\
\hline 86. NM_0II664 & Ubb & $1.86 \mathrm{E}-05$ & Ubiquitination and protein degradation \\
\hline 87. NM_008037 & Fos 12 & I.88E-05 & Forming the transcription factor complex AP-I \\
\hline 88. - & & $1.88 \mathrm{E}-05$ & N/A \\
\hline 89. NM_0223I2 & $T n r$ & $1.88 \mathrm{E}-05$ & Mediates inhibition of cell adhesion and neurite outgrowth \\
\hline 90. NM_011693 & Vcam I & I.89E-05 & $\begin{array}{l}\text { Mediates leukocyte-endothelial cell adhesion and signal } \\
\text { transduction }\end{array}$ \\
\hline 91. NM_145706 & Nup43 & I.89E-05 & $\begin{array}{l}\text { Required for microtubule attachment, mitotic progression and } \\
\text { chromosome segregation }\end{array}$ \\
\hline 92. NM_0I2003 & Cops7a & I.90E-05 & Involved in various cellular and developmental processes \\
\hline 93. NM_I45823 & Pitpncl & I.91E-05 & Involved in cell signaling and lipid metabolism \\
\hline 94. NM_00880I & Pde6d & $1.94 \mathrm{E}-05$ & Involved in cellular signal transduction \\
\hline 95. NR_028528 & Snord57 & $1.95 \mathrm{E}-05$ & Small nucleolar RNA \\
\hline 96. NM_008086 & Gas I & $1.96 \mathrm{E}-05$ & Involved in growth suppression \\
\hline 97. NR_004445 & Snord22 & $2.01 \mathrm{E}-05$ & Small nucleolar RNA \\
\hline 98. NM_001III3486 & & 2.01E-05 & N/A \\
\hline 99. NM_026667 & Fam $/ \mid 4 a l$ & 2.06E-05 & Plays a role in neuronal cell development \\
\hline 100. NM_00II66065 & Gent4 & 2.09E-05 & Glycosyltransferase \\
\hline 101. NM_0254I5 & Cks2 & 2.IIE-05 & Binds to cyclin dependent kinases \\
\hline 102. NM_001081229 & $T s c 22 d 2$ & $2.12 \mathrm{E}-05$ & Function unknown \\
\hline 103. NM_0II923 & Angpt/2 & $2.12 \mathrm{E}-05$ & Induces sprouting in endothelial cells \\
\hline
\end{tabular}

(Continued) 
Table SI (Continued)

\begin{tabular}{|c|c|c|c|}
\hline Ref seq & Gene symbol & $\begin{array}{l}P \text {-value (observed } \\
\text { group) }\end{array}$ & Molecular function \\
\hline 104. NM_0II664 & Ubb & 2.15E-05 & Ubiquitination and protein degradation \\
\hline I05. ENSMUST00000I05363 & Gamt & 2.16E-05 & Methyltransferase \\
\hline 106. NM_0II654 & Tubalb & 2.16E-05 & Interaction with PI3KRI \\
\hline I07. NM_00II59288 & Morc2a & 2.18E-05 & Transcriptional repressor \\
\hline 108. NM_010560 & Il6st & $2.30 \mathrm{E}-05$ & Signal-transducing molecule \\
\hline 109. - & & $2.3 \mathrm{IE}-05$ & $\mathrm{~N} / \mathrm{A}$ \\
\hline II0. NM_I78403 & Pus7 & $2.32 \mathrm{E}-05$ & Catalyzes pseudouridylation \\
\hline III. NM_001030307 & $D k c l$ & $2.34 \mathrm{E}-05$ & Required for ribosome biogenesis and telomere maintenance \\
\hline I 12. NM_008197 & HIfO & $2.35 \mathrm{E}-05$ & $\begin{array}{l}\text { Required for the condensation of nucleosome chains into } \\
\text { higher-order structures }\end{array}$ \\
\hline I I3. NM_028I56 & I 70000 IPO IRik & $2.40 \mathrm{E}-05$ & Function unknown \\
\hline I |4. NM_00887| & Serpine I & $2.45 \mathrm{E}-05$ & Serine protease inhibitor \\
\hline II5. L0865I & Rp/29 & $2.46 \mathrm{E}-05$ & Ribosomal protein \\
\hline II6. - & & $2.48 \mathrm{E}-05$ & N/A \\
\hline II7. NM_00II98985 & Tjp2 & $2.50 \mathrm{E}-05$ & Plays a role in tight junctions and adherens junctions \\
\hline I I8. NM_027349 & $R b m 25$ & $2.55 \mathrm{E}-05$ & A regulator of alternative pre-mRNA splicing \\
\hline II9. NM_00III0310 & $\operatorname{Sn} x 12$ & $2.66 \mathrm{E}-05$ & Involved in several stages of intracellular trafficking \\
\hline 120. NM_I786I5 & $\operatorname{Rgmb}$ & $2.79 \mathrm{E}-05$ & Promotes neuronal adhesion \\
\hline I2I. NM_0I0234 & Fos & 2.79E-05 & Forms the transcription factor complex AP-I \\
\hline 122. NM_0II8I2 & Fbln5 & $2.82 \mathrm{E}-05$ & Plays a role in vascular development and remodeling \\
\hline $123 .-$ & & $2.83 \mathrm{E}-05$ & N/A \\
\hline 124. NM_00I0I3762 & Gm4952 & $2.86 \mathrm{E}-05$ & Function unknown \\
\hline 125. NM_00II90466 & Dact l & 2.87E-05 & Involved in regulation of intracellular signaling pathways \\
\hline 126. NM_029999 & Lbh & 2.94E-05 & Involved in MAP kinase signaling pathway \\
\hline 127. NM_0I0026 & Asapl & 2.94E-05 & Involved in the differentiation of fibroblasts into adipocytes \\
\hline 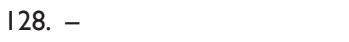 & & $2.98 \mathrm{E}-05$ & N/A \\
\hline I29. ENSMUST000000I2348 & Gstm2 & 2.99E-05 & Glutathione S-transferase \\
\hline 130. NM_00I080I29 & Tmpo & 2.99E-05 & Helps maintain the structural organization of the nuclear envelope \\
\hline |3|. NM_0II898 & Spry4 & $3.06 \mathrm{E}-05$ & $\begin{array}{l}\text { Suppresses the insulin receptor and EGFR-transduced MAPK } \\
\text { signaling pathway }\end{array}$ \\
\hline |32. NM_026II5 & Hat I & 3.17E-05 & Plays a role in DNA repair \\
\hline |33. NM_I7859I & $\mathrm{Nrgl}$ & 3.18E-05 & $\begin{array}{l}\text { Plays critical roles in the growth and development of multiple } \\
\text { organ systems }\end{array}$ \\
\hline |34. NR_046|44 & $R n 5 s 20$ & 3.19E-05 & Required for transcription \\
\hline I35. NM_|45354 & Nsun2 & $3.20 \mathrm{E}-05$ & RNA methyltransferase \\
\hline I36. NM_00IIII059 & $\mathrm{Cd} 34$ & $3.28 \mathrm{E}-05$ & Plays a role in the attachment of stem cells to stromal cells \\
\hline I37. NM_00I204233 & Sppl & $3.29 \mathrm{E}-05$ & Involved in enhancing production of interferon-gamma \\
\hline I38. NM_026864 & Rasll la & $3.30 \mathrm{E}-05$ & Ras signaling \\
\hline 139. NM_1337|4 & Kansl2 & $3.32 \mathrm{E}-05$ & Involved in acetylation of nucleosomal histone $\mathrm{H} 4$ \\
\hline 140. NM_021389 & Sh3kbpl & $3.36 \mathrm{E}-05$ & Involved in apoptosis, cytoskeletal rearrangement, cell adhesion \\
\hline$|4| .-$ & & 3.37E-05 & N/A \\
\hline 142. NM_009609 & Actgl & $3.38 \mathrm{E}-05$ & Involved in various types of cell motility \\
\hline 143. NM_0II859 & Osrl & $3.38 \mathrm{E}-05$ & Transcription factor \\
\hline 144. NM_010256 & Gart & $3.43 \mathrm{E}-05$ & Required for De novo purine biosynthesis \\
\hline |45. NM_0I|435 & Sod3 & $3.44 \mathrm{E}-05$ & Antioxidant enzymes \\
\hline 146. - & & $3.46 \mathrm{E}-05$ & N/A \\
\hline 147. - & & 3.47E-05 & N/A \\
\hline I48. NM_I78604 & $T x n 14 a$ & $3.48 \mathrm{E}-05$ & Essential role in pre-mRNA splicing \\
\hline 149. ВC089624 & Rpl7a & $3.53 \mathrm{E}-05$ & Catalyzes protein synthesis \\
\hline I50. NM_008047 & Fstll & $3.54 \mathrm{E}-05$ & Modulates the action of some growth factors \\
\hline |5I. NM_207|6I & $B C 048355$ & $3.58 \mathrm{E}-05$ & Function unknown \\
\hline I52. NM_009626 & Adh7 & $3.70 \mathrm{E}-05$ & Required for synthesis of retinoic acid \\
\hline |53. NM_I7230I & Ccnbl & 3.7IE-05 & A regulatory protein involved in mitosis \\
\hline 154. NM_0I3543 & $\mathrm{H} 2-\mathrm{Ke} 6$ & $3.73 \mathrm{E}-05$ & Plays a role in biosynthesis of fatty acids in mitochondria \\
\hline I55. NM_00I08I277 & $A k 5$ & $3.74 \mathrm{E}-05$ & Involved in regulating the adenine nucleotide composition \\
\hline I56. NM_I81390 & Mustn I & 3.79E-05 & $\begin{array}{l}\text { Involved in the development and regeneration of the } \\
\text { musculoskeletal system }\end{array}$ \\
\hline
\end{tabular}


Table SI (Continued)

\begin{tabular}{|c|c|c|c|}
\hline Ref seq & Gene symbol & $\begin{array}{l}P \text {-value (observed } \\
\text { group) }\end{array}$ & Molecular function \\
\hline I57. NM_009498 & Vamp3 & $3.84 \mathrm{E}-05$ & $\begin{array}{l}\text { Involved in vesicular transport from the late endosomes to the } \\
\text { trans-Golgi network }\end{array}$ \\
\hline I58. NM_027722 & Nudt4 & $3.86 \mathrm{E}-05$ & Plays a role in signal transduction \\
\hline I59. NM_022324 & Sdf2II & 3.87E-05 & Function unknown \\
\hline 160. NM_00762I & Cbr2 & $3.88 \mathrm{E}-05$ & Plays a role in the uronate cycle of glucose metabolism \\
\hline 16I. NM_026369 & Arpc5 & 4.07E-05 & Involved in regulation of actin polymerization \\
\hline 162. AK079043 & Gm9908 & 4.09E-05 & Function unknown \\
\hline 163. NM_0II4I5 & Snai2 & 4.10E-05 & Transcriptional repressor \\
\hline I64. NM_008027 & Flotl & 4.I3E-05 & Involved in vesicular trafficking and signal transduction \\
\hline 165. NM_0I|452 & Serpinb9b & 4.14E-05 & Granzyme B inhibitor \\
\hline 166. NM_00II00454 & WfikknI & 4. $18 \mathrm{E}-05$ & Protease inhibitor \\
\hline 167. NM_016750 & H2afz & 4.22E-05 & $\begin{array}{l}\text { Plays a central role in transcription regulation, DNA repair, } \\
\text { DNA replication and chromosomal stability }\end{array}$ \\
\hline 168. NM_028626 & Mcee & 4.29E-05 & Function unknown \\
\hline 169. NM_010729 & Loxll & $4.32 \mathrm{E}-05$ & $\begin{array}{l}\text { Plays roles in developmental regulation, senescence, tumor } \\
\text { suppression }\end{array}$ \\
\hline 170. NR_034052 & Snora $2 b$ & 4.33E-05 & Small nucleolar RNA \\
\hline |7|. NM_| 466151 & Tesk2 & 4.35E-05 & Plays an important role in spermatogenesis \\
\hline |72. NM_01957| & Tspan5 & 4.36E-05 & Mediates signal transduction events \\
\hline 173. - & & 4.44E-05 & N/A \\
\hline 174. NM_0II297 & Rps24 & $4.48 \mathrm{E}-05$ & Required for processing of pre-rRNA \\
\hline 175. NR_004432 & Rnul2 & 4.49E-05 & RNA gene \\
\hline 176. NM_007436 & Aldh3al & $4.50 \mathrm{E}-05$ & $\begin{array}{l}\text { Involved in the metabolism of corticosteroids, biogenic amines, } \\
\text { neurotransmitters, and lipid peroxidation }\end{array}$ \\
\hline I77. NM_009504 & $V d r$ & 4.50E-05 & Nuclear hormone receptor \\
\hline I78. NM_029645 & Gatc & 4.59E-05 & $\begin{array}{l}\text { Allows the formation of correctly charged Gln-tRNA in the } \\
\text { mitochondria }\end{array}$ \\
\hline 179. NM_I45360 & Idil & 4.59E-05 & $\begin{array}{l}\text { Required for the synthesis of farnesyl diphosphate and } \\
\text { cholesterol }\end{array}$ \\
\hline 180. NM_053273 & Ttyh2 & 4.59E-05 & Involved in cell proliferation and cell aggregation \\
\hline I8I. NM_I73756 & $\operatorname{Lin} 52$ & 4.6IE-05 & Represses cell cycle-dependent genes \\
\hline 182. ENSMUST00000064795 & Egrl & $4.6 I E-05$ & $\begin{array}{l}\text { Activates the transcription of target genes whose products are } \\
\text { required for mitogenesis and differentiation }\end{array}$ \\
\hline I83. NM_010308 & Gnaol & 4.64E-05 & Transducers in transmembrane signaling systems \\
\hline 184. NM_008304 & Sdc2 & $4.66 \mathrm{E}-05$ & $\begin{array}{l}\text { Mediates cell binding, cell signaling, and cytoskeletal } \\
\text { organization }\end{array}$ \\
\hline 185. NM_029809 & $23100 / 4 L I 7 R i k$ & 4.66E-05 & Function unknown \\
\hline 186. NM_009830 & Cone2 & $4.68 \mathrm{E}-05$ & $\begin{array}{l}\text { Essential for the control of the cell cycle at the late GI and } \\
\text { early S phase }\end{array}$ \\
\hline 187. ENSMUST00000067692 & $\operatorname{Rad} 5 / c$ & 4.7IE-05 & $\begin{array}{l}\text { Essential for the homologous recombination pathway of DNA } \\
\text { repair }\end{array}$ \\
\hline 188. NM_010219 & Fkbp4 & 4.76E-05 & Plays a role in the intracellular trafficking \\
\hline I89. NM_I72590 & Wdr4I & $4.78 \mathrm{E}-05$ & Function unknown \\
\hline 190. NM_I77370 & Rhbdd3 & 4.8IE-05 & Function unknown \\
\hline 191. ENSMUST00000027009 & Casp 12 & 4.83E-05 & Reduces activation of NF-kappa-B in response to TNF \\
\hline 192. NM_02I504 & Nglyl & $4.90 \mathrm{E}-05$ & $\begin{array}{l}\text { Plays a role in the proteasome-mediated degradation of } \\
\text { misfolded glycoproteins }\end{array}$ \\
\hline 193. NM_I46206 & Tpcn2 & 4.98E-05 & Involved in smooth muscle contraction \\
\hline 194. NM_I72784 & Lrp II & 5.0IE-05 & Function unknown \\
\hline 195. NM_0I8773 & Skap2 & $5.02 \mathrm{E}-05$ & Plays a role in src signaling pathway \\
\hline 196. NM_028234 & Rbm33 & $5.06 \mathrm{E}-05$ & Function unknown \\
\hline 197. ENSMUUST00000097772 & $\|l \mid r\|$ & $5.18 \mathrm{E}-05$ & Involved in helper $\mathrm{T}$ cell function \\
\hline |98. NM_02387| & Set & $5.24 \mathrm{E}-05$ & $\begin{array}{l}\text { Involved in apoptosis, transcription, nucleosome assembly and } \\
\text { histone chaperoning }\end{array}$ \\
\hline 199. NM_0074I3 & Adora $2 b$ & 5.29E-05 & Involved in axon elongation \\
\hline 200. NM_0077I3 & Clk3 & $5.30 \mathrm{E}-05$ & $\begin{array}{l}\text { Dual specificity kinase acting on both serine/threonine and } \\
\text { tyrosine-containing substrates }\end{array}$ \\
\hline
\end{tabular}

Abbreviation: N/A, not available. 


\section{Publish your work in this journal}

Drug Design, Development and Therapy is an international, peerreviewed open-access journal that spans the spectrum of drug design and development through to clinical applications. Clinical outcomes, patient safety, and programs for the development and effective, safe, and sustained use of medicines are a feature of the journal, which

has also been accepted for indexing on PubMed Central. The manuscript management system is completely online and includes a very quick and fair peer-review system, which is all easy to use. Visit http://www.dovepress.com/testimonials.php to read real quotes from published authors.

Submit your manuscript here: http://www.dovepress.com/drug-design-development-and-therapy-journal 